\title{
Climate and fragmentation affect forest structure in the southern border of
}

\section{Amazonia}

Simone Matias Reis ${ }^{\mathrm{a}, \mathrm{b}}$, Beatriz Schwantes Marimon ${ }^{\mathrm{b}, \mathrm{c}, *}$, Ben Hur Marimon Junior ${ }^{\mathrm{b}, \mathrm{c}}$, Paulo S. Morandi ${ }^{\mathrm{a}, \mathrm{b}}$, Edmar Almeida de Oliveira ${ }^{\mathrm{b}}$, Fernando Elias ${ }^{\mathrm{c}}$, Eder Carvalho das Neves $^{\mathrm{c}}$, Bianca de Oliveira ${ }^{\mathrm{c}}$, Denis Silva Nogueira ${ }^{\mathrm{c}}$, Ricardo Keichi Umetsu ${ }^{\mathrm{c}}$, Ted R. Feldpausch ${ }^{\mathrm{c}, \mathrm{d}}$ and Oliver L. Phillips ${ }^{\mathrm{a}}$

${ }^{a}$ School of Geography, University of Leeds, Leeds, United Kingdom; ${ }^{b}$ Programa de PósGraduação da Rede de Biodiversidade e Biotecnologia da Amazônia Legal (BIONORTE), Universidade do Estado de Mato Grosso-Universidade Federal do Amazonas, Nova Xavantina, Mato Grosso, Brazil; ' ${ }^{C}$ niversidade do Estado de Mato Grosso, Programa de Pós-graduação em Ecologia e Conservação, Nova Xavantina, MT, Brazil; 'University of Exeter, Geography, College of Life and Environmental Sciences, Exeter, United Kingdom

*Corresponding author. Email: biamarimon@unemat.br

\section{Citation:}

Reis, S. M., B. S. Marimon, B. H. Marimon Junior, P. S. Morandi, E. A. d. Oliveira, F. Elias, E. C. d. Neves, B. d. Oliveira, D. d. S. Nogueira, R. K. Umetsu, T. R. Feldpausch, and O. L. Phillips. 2018. Climate and fragmentation affect forest structure at the southern border of Amazonia. Plant Ecology \& Diversity:1-11. 
30 Abstract

31 Background: The remaining forests in the extensive contact zone between southern

32 Amazonia (seasonal rain forest) and the Cerrado (savanna) biomes are at risk due to 33 intense land-use and climate change.

34 Aims: To explore the vulnerability of these transitional forests to changes in land use 35 and climate, we evaluated the effects of fragmentation and climatic variables on forest 36 structure.

37 Methods: We measured the diameter and height of 14,185 trees with diameter $\geq 10 \mathrm{~cm}$ 38 at 24 forest plots distributed over an area of $25,000 \mathrm{~km}^{2}$. For each plot, we obtained data 39 on contemporary fragmentation and climatic variables.

40 Results: Forest structure variables (height, diameter, height:diameter allometry, 41 biomass) varied significantly both within and among plots. The height, $H: D$ and 42 biomass of trees were positively correlated with annual precipitation and fragment area.

43 Conclusions: The association between forest structure and precipitation indicates that 44 these forests plots are likely to be vulnerable to dry season intensification anticipated for 45 the southern edge of the Amazon. Additionally, the reduction in the fragment area may 46 contribute to reductions in forest biomass and tree height, and consequently ecosystem 47 carbon stocks. Given the likely susceptibility of these forests, urgent conservation action is needed to prevent further habitat degradation. 
50 Keywords: allometry; Amazon arc of deforestation; biomass; climate change; habitat fragmentation; precipitation; stem diameter; tree height; transition zone

\section{Introduction}

Across the Earth's biomes, environmental conditions are expected to be

more variable close to the edges than in the core area of each biome, posing potentially ecological and evolutionary challenges to biota towards their biogeographical edges (Safriel et al. 1994; Kark and van Rensburg 2006; Kark et al. 2008). This may be particularly the case in regions subject to rapid environmental change, of which perhaps the most extreme example are the forests of the southern edge of the Amazon rain forest biome, an area affected by high deforestation rates and subject to significant recent and forecast climate change. Thus, here the advance of the agricultural frontier has already resulted in converting most forest to pasture and cropland, increasingly fragmenting the landscape over the last few decades (Alencar et al. 2004, 2015; Nogueira et al. 2008). The remaining forests are subject to recent climate change, including lengthening of the dry season and increasing incidence of strong droughts (Marengo et al. 2011; Gloor et al. 2015; Feldpausch et al. 2016), trends which are expected to intensify further (e.g. Boisier et al. 2015). The land surface temperature has been rising steadily recently, especially in the south and east of the Amazon region (Jiménez-Muñoz et al. 2013), and the effects of these climatic changes may be exacerbated by changes in land use (Aragão 2012; Silvério et al. 2015). Finally, research elsewhere in Amazonia clearly has indicated that the structure of the tropical forest vegetation is affected by both climate change (e.g. Phillips et al. 2010; Feldpausch et al. 2016) and fragmentation of habitats (e.g. Laurance et al. 1997, 2000; Laurance 2004). 
Yet few studies have evaluated structural variation among the forests in the

Habitat fragmentation, by decreasing fragment size and increasing forest edges and numbers of fragments, may modify the forest structure in the remaining fragments (Fahring 2003; Haddad et al. 2015). For example, fragment edges are subject to a greater incidence of insolation and increased velocity of winds, resulting in higher temperatures and a drier microclimate than the forest interior (D'Angelo et al. 2004; Laurance 2004; Haddad et al. 2015), which increases tree mortality rates, principally for larger trees (Laurance et al. 2000; Laurance 2004). The death of bigger trees reduces total biomass, height, mean diameter and basal area, especially in the smaller fragments and the areas closest to the forest edge, although with some mortality effects also propagating a few hundred meters into the forest (Laurance 2004; Haddad et al. 2015; Rocha-Santos et al. 2016). Recently, it has even been suggested, based on interpretation of pantropical satellite imagery, that in tropical forests the negative effects on standing biomass and forest structure penetrate as much as $1.5 \mathrm{~km}$ into forests (Chaplin-Kramer et al. 2015). 
In addition to landscape-scale factors, regional climate is related to variation in the forest structure (e.g. Banin et al. 2015). For example, where precipitation and temperature are higher, forests generally have taller trees that accumulate more biomass

101 (Koch et al. 2004; Way and Oren 2010; Feldpausch et al. 2011; Pan et al. 2013; Chave 102 et al. 2014). However, in the very warmest forests the forest structural responses are 103 unclear. There is some evidence that here plants may photosynthesise less and expend more energy on respiration, so potentially accumulating less biomass (Lloyd and Farquhar 2008; Lewis et al. 2013). However, the temperature sensitivity of key respiration processes appears to decline in warmer environments (Atkin et al. 2015,

107 Heskel et al. 2016), rather than increasing exponentially as simple $\mathrm{Q}_{10}$ formulations in 108 earlier global vegetation models suggested (Cox et al. 2000), suggesting that the overall sensitivity of biomass stocks to high temperatures might be weaker than many models 110 indicated. Extreme drought events may alter the forest structure. Drought causes

112 mortality, principally in the bigger trees, which are more susceptible to damage in their 113 vascular system (Phillips et al. 2010; Rowland et al. 2015; Bennett et al. 2015; 114 Feldpausch et al. 2016). During drought events, tropical trees may also grow less (e.g. 115 Worbes 1999; Doughty et al. 2015), and if droughts are prolonged or repeated forests 116 eventually accumulate less biomass (Feldpausch et al. 2016; Rowland et al. 2015).

117 In the context of regional land-use and climatic changes in southern Amazonia, 118 and the projected high regional climate sensitivity to global warming (IPCC 2015), it is 119 therefore extremely important to understand how the forest structure is affect by abiotic 120 factors. It may for example help to improve the conservation measures to protect the 121 remaining forest fragments. In this study, we evaluated whether, and to what extent, 
122 climatic factors and fragmentation determine variation in the forest structure of the

123 southern Amazon border. We assembled data from permanent plots established across

124 the region close to the natural border of Amazonia with the neighboring Cerrado

125 (savanna) biome, to test hypotheses related to the variation in the forest structure and

126 the factors that determine this variation. We addressed two questions. First, does habitat

127 fragmentation affect the forest structure? We expected that forest cover loss and forest

128 plots present in smaller fragments and/or nearer the edge would have trees with lower

129 height and smaller diameter stems, or with smaller height:diameter $(H: D)$ allometric

130 relationships and reduced biomass, since work elsewhere has shown mortality rates are

131 greater in smaller, more edge-affected fragments, especially for bigger trees (e.g.

132 Laurance et al. 1997, 1998, 2000; Laurance 2004; Chaplin-Kramer et al. 2015). Second,

133 how does the forest structure vary in relation to the climate? We expected that the

134 height and the diameter of stems, the $H: D$ ratio, and biomass were all greater in forest

135 plots that have greater precipitation, and consequently less deficit water, since the

136 greater water availability favours the height growth of the trees, accumulating more

137 biomass (e.g. Feldpausch et al. 2011; Pan et al. 2013; Chave et al. 2014).

139 Materials and methods

140 Study area

141 We studied 24 forest plots distributed in the so-called 'arc of deforestation'

142 (Nogueira et al. 2008) over an area of ca. 25,000 $\mathrm{km}^{2}$ (Figure 1 and Table 1). The

143 regional climate is of the $A w$ (tropical with dry winters) and $A m$ (tropical monsoon)

144 types in the Köppen classification system (Alvares et al. 2013), and originally supported

145 evergreen or semi-evergreen forest vegetation in all cases. Mean annual precipitation 
147 (Table 1).

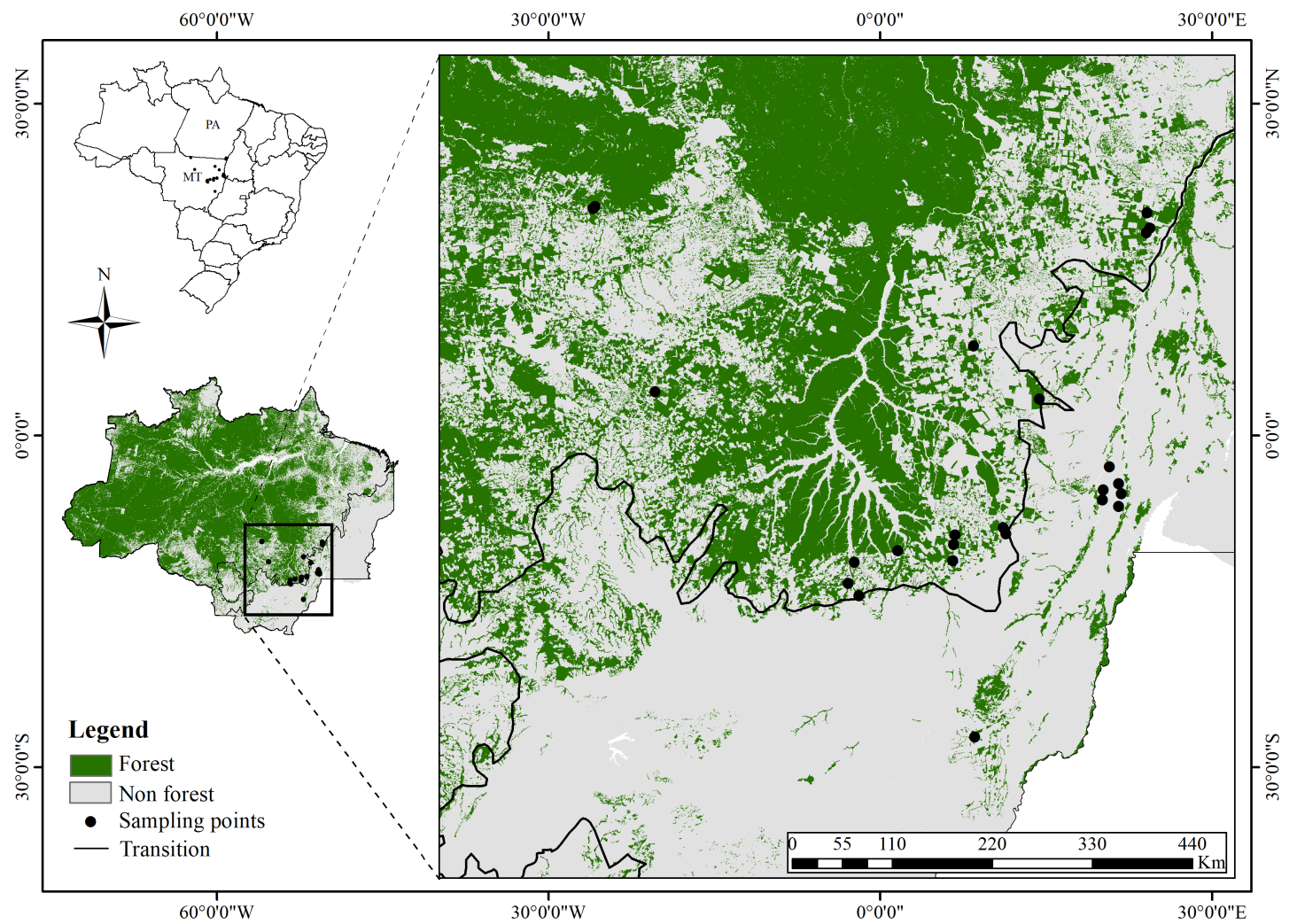

149 Figure 1. Location of the forests sampled in the southern Amazon border, between

150 eastern and northern Mato Grosso and southern Pará, Brazil, showing the approximate

151 biome boundaries based in IBGE (2004). The classification of forest and no forest was

152 based on the PRODES (Amazon Deforestation Monitoring Project) (INPE 2017). All

153 plots sampled lie within mature, evergreen or semi-evergreen forest fragments.

155 Table 1. Characteristics of plots sampled in different tropical forest ecosystems at the

156 southern Amazon border. FA, fragment area; DE, distance to the forest edge; Prec, total

157 mean annual precipitation; Temp, mean annual temperature; TB, total above-ground

158 biomass per hectare; PP, private properties; and CU, conservation unit. In this study, we used codes ('Plot code') to represent the different types of vegetation: FEP, floresta 
160 estacional perenifólia (seasonal evergreen forest), FTP, floresta estacional perenifólia

161 em terra preta de índio (seasonal evergreen forest on anthropogenic black earth); FES,

162 floresta estacional semidecidual (seasonal semi-deciduous forest); FOA, floresta

163 ombrófila aberta (open rainforest); and FSI, floresta sazonalmente inundável

164 (seasonally flooded forest). Equivalent forest plot codes are given to indicate

165 equivalency to those codes used in the ForestPlots.net database (Lopez-Gonzalez et al.

166 2011) where the data have been deposited.

\begin{tabular}{|c|c|c|c|c|c|c|c|c|}
\hline $\begin{array}{l}\text { Plot } \\
\text { Code }\end{array}$ & $\begin{array}{l}\text { Forest plot } \\
\text { code }\end{array}$ & $\begin{array}{l}\text { Geographical } \\
\text { coordinate }\end{array}$ & Local & $\begin{array}{l}\mathrm{AF} \\
\text { (ha) }\end{array}$ & $\begin{array}{l}\mathrm{DE} \\
(\mathrm{m})\end{array}$ & $\begin{array}{l}\text { Prec } \\
(\mathrm{mm})\end{array}$ & $\begin{array}{l}\text { Temp } \\
\left({ }^{\circ} \mathrm{C}\right)\end{array}$ & $\begin{array}{c}\mathrm{TB} \\
(\mathrm{Mg})\end{array}$ \\
\hline FEP-01 & FLO-01 & $-12.8 \mathrm{~S}$ and $-51.9 \mathrm{~W}$ & $\mathrm{PP}$ & 870 & 1,030 & 1613 & 25.5 & 111.1 \\
\hline FEP-02 & FLO-02 & $-12.8 \mathrm{~S}$ and $-51.9 \mathrm{~W}$ & PP & 2,035 & 1,000 & 1621 & 25.6 & 144.7 \\
\hline FEP-03 & TAN-02 & $-13.1 \mathrm{~S}$ and $-52.4 \mathrm{~W}$ & PP & 8,432 & 990 & 1625 & 24.9 & 143.5 \\
\hline FEP-04 & TAN-03 & $-12.8 \mathrm{~S}$ and $-52.3 \mathrm{~W}$ & PP & 16,901 & 520 & 1679 & 25.1 & 127.4 \\
\hline FEP-05 & TAN-04 & $-12.9 \mathrm{~S}$ and $-52.4 \mathrm{~W}$ & PP & 16,901 & 329 & 1662 & 25 & 138.3 \\
\hline FEP-06 & FRP-01 & $-11.5 \mathrm{~S}$ and $-51.5 \mathrm{~W}$ & PP & 45,459 & 3,600 & 1634 & 26.9 & 135.1 \\
\hline FEP-07 & POA-01 & $-11.0 \mathrm{~S}$ and $-52.2 \mathrm{~W}$ & PP & 9,789 & 1,180 & 1772 & 26.1 & 140.1 \\
\hline FES-01 & VCR-02 & $-14.8 \mathrm{~S}$ and $-52.2 \mathrm{~W}$ & PP & 4,968 & 1,350 & 1511 & 25.2 & 196.8 \\
\hline FES-02 & GAU-02 & $-13.4 \mathrm{~S}$ and $-53.3 \mathrm{~W}$ & PP & 3,499 & 160 & 1701 & 24.1 & 91.7 \\
\hline FES-03 & SAT-01 & $-9.8 \mathrm{~S}$ and $-50.5 \mathrm{~W}$ & PP & 17,624 & 90 & 1821 & 26.7 & 121.8 \\
\hline FES-04 & SAA-01 & $-9.8 \mathrm{~S}$ and $-50.4 \mathrm{~W}$ & PP & 13,039 & 860 & 1815 & 26.8 & 187.7 \\
\hline FES-05 & SAA-02 & $-9.6 \mathrm{~S}$ and $-50.4 \mathrm{~W}$ & PP & 15,680 & 2,980 & 1778 & 26.6 & 166.3 \\
\hline FOA-01 & SIP-01 & $-11.4 \mathrm{~S}$ and $-55.3 \mathrm{~W}$ & PP & 12,066 & 900 & 1848 & 25.1 & 79.2 \\
\hline FOA-02 & ALF-01 & $-9.6 \mathrm{~S}$ and $-55.9 \mathrm{~W}$ & $\mathrm{CU}$ & 17,628 & 5,440 & 2350 & 25.5 & 98.8 \\
\hline FOA-03 & ALF-02 & $-9.6 \mathrm{~S}$ and $-55.9 \mathrm{~W}$ & $\mathrm{CU}$ & 17,628 & 5,410 & 2353 & 25.6 & 160.5 \\
\hline FSI-01 & PEA-01 & $-12.1 \mathrm{~S}$ and $-50.8 \mathrm{~W}$ & $\mathrm{CU}$ & 21 & 1 & 1631 & 27.3 & 133.7 \\
\hline FSI-02 & PEA-02 & $-12.3 \mathrm{~S}$ and $-50.7 \mathrm{~W}$ & $\mathrm{CU}$ & 378 & 1 & 1637 & 27.2 & 154.7 \\
\hline FSI-03 & PEA-03 & $-12.4 \mathrm{~S}$ and $-50.9 \mathrm{~W}$ & $\mathrm{CU}$ & 164 & 1 & 1621 & 27.1 & 131.4 \\
\hline FSI-04 & PEA-04 & $-12.4 \mathrm{~S}$ and $-50.7 \mathrm{~W}$ & $\mathrm{CU}$ & 605 & 1 & 1637 & 27.1 & 210.4 \\
\hline FSI-05 & PEA-07 & $-12.5 \mathrm{~S}$ and $-50.9 \mathrm{~W}$ & $\mathrm{CU}$ & 5 & 1 & 1621 & 27.1 & 226.8 \\
\hline FSI-06 & PEA-08 & $-12.5 \mathrm{~S}$ and $-50.7 \mathrm{~W}$ & $\mathrm{CU}$ & 8 & 1 & 1632 & 27 & 222.5 \\
\hline FTP-01 & GAU-04 & $-13.1 \mathrm{~S}$ and $-53.3 \mathrm{~W}$ & PP & 234 & 150 & 1795 & 24.7 & 145.8 \\
\hline FTP-02 & GAU-05 & $-13.0 \mathrm{~S}$ and $-52.9 \mathrm{~W}$ & PP & 29,560 & 2,720 & 1757 & 24.9 & 250.2 \\
\hline FTP-03 & GAU-06 & $-13.3 \mathrm{~S}$ and $-53.4 \mathrm{~W}$ & PP & 85 & 80 & 1729 & 24.7 & 176.9 \\
\hline
\end{tabular}

167

168 Forest fragments

The largest and best preserved regional fragments of mature forests were

170 selected for the study, using Google Earth imagery in order to capture regional variation

171 in floristics and physiognomy, and with at least three plots for each forest type. All 
172 forest fragments are surrounded by extensive cattle-ranching or soybean fields. The

173 fragments surveyed varied in size from 5 to 45,459 ha (Table 1).

174

Forest structure

In each fragment we established an inventory plot of 1 ha, which was

177 subdivided into 25 contiguous subplots of $20 \mathrm{~m} \times 20 \mathrm{~m}$. The forest plots were established between 2008 and 2016 within the private properties and in conservation units; locations varied between 1 and $5440 \mathrm{~m}$ from the nearest edge of the fragment. Six

180 plots were seasonally flooded (Table 1) and occasionally affected by fire; the others

181 have no recent record of fire and were either on anthropogenic black earth (terra preta

182 de indio), open rain forests, seasonal evergreen forests, or seasonal semi-deciduous 183 forests (Table 1). For this study, we used the latest available censuses between 2013 and 1842016.

We identified and tagged all the woody individuals with a diameter at breast

186 height $(1.3 \mathrm{~m})$ of $\geq 10 \mathrm{~cm}$, for a total of $14,185($ range $=338-1599 ;$ standard deviation $=$

$18731)$ trees and at least $410($ range $=9-135$; standard deviation $=256)$ taxa identified to 188 species level. We identified species in the field or by comparison of collections with

189 herbarium (NX, UFMT, UB and IAN) material of known identity, and with the help of 190 specialists. After identification, the material was incorporated into Herbarium NX, Nova

191 Xavantina, Mato Grosso (Coleção Zoobotânica James Alexander Ratter). We 192 determined the classification of families based on APG III (Angiosperm Phylogeny 193 Group 2009) and reviewed and updated the nomenclature of the taxa using the Lista de 194 Espécies da Flora do Brasil (http://floradobrasil.jbrj.gov.br/2015). 
We measured the diameter of each tree following standard protocols of the

RAINFOR network (http://www.rainfor.org/). We measured the total height using a

197 Leica DISTO laser measurement device. Data were deposited in the ForestPlots.net

198 forest monitoring database (Lopez-Gonzalez et al. 2011).

Habitat fragmentation

To evaluate the effect of habitat fragmentation on forest structure, we measured distance from each plot to the forest edge, the size of each fragment and the forest cover in surrounding landscapes. Whenever possible we measured the distance to

204 the nearest edge in the field. When this was not possible, we estimated this value using

205 Google Earth, which provided a spatial resolution of approximately 20 to $30 \mathrm{~m}$ depending on available imagery, and based on our own detailed knowledge, having explored the local context of each plot on foot. In our definition of forest habitat edge, we included all other vegetation and land-use such as plantations, pastures, and roads at least $25 \mathrm{~m}$ wide, as well as natural grasslands in the six floodplain forests.

We calculated the area of the fragment where each plot was located using

211 Google Earth and ZONUM software (http://zonums.com/online/kmlArea/). These edge

212 and fragment data were collected at the closest possible date to the field sampling and in

213 no case were they collected more than 2 years after the last forest census.

214 We calculated the percentage of forest cover surrounding each plot using

215 buffers of radius size of $1000 \mathrm{~m}$ (314 ha), following recommendations of Rocha-Santos

216 et al. (2016). For this we used the land-based metrics in the Fragstats software, that

217 computes descriptors of forest patch and landscape attributes (McGarigal and Cushman 218 2002). 
Climate variables

To evaluate the climate effect on the forest structure, we obtained data on 19

222 bioclimatic variables (Table S1) from the WorldClim 1.4 database, with a horizontal

223 resolution of ca. $1 \mathrm{~km}$ (Hijmans et al. 2005). We also used data from the Tropical

224 Rainfall Monitoring Mission (TRMM) (NASA 2012) to derive the mean of the annual maximum climatological water deficit (MCWD) (Aragão et al. 2007) between January 1999 and December 2011, including the droughts of 2005, 2007 and 2010 (Figure S2).

To estimate this, we first calculated MCWD for each year, and then took the mean of all years. MCWD was defined as the most negative value of climatological water deficit (precipitation lower than evapotranspiration) among all the months in each year.

Data analysis

In each plot, we calculated the minimum, maximum, median, and 95 percentile of tree diameter $(D)$, height $(H)$ and their allometric $(H: D)$ relationship. We

234 also calculated the weighted Lorey's height values, based on basal area per subplot, 235 using the equation

$$
\sum \mathrm{AB}_{i} * H_{i} / \sum \mathrm{AB}_{i},
$$

237 where $\mathrm{AB}_{i}$ is the basal area of an individual and $H_{i}$ is its height (e.g. Saatchi et al. 2011).

238 To evaluate the $H: D$ relationship, independently of disturbance, such as the damage 239 caused by recently-opened clearings, we excluded from the analyses all trees with broken stems or those with more than $50 \%$ of the crown broken off. 
We also calculated the mean, median, and total biomass of trees per plot.

242 We estimated the biomass $(B)$ based on the Pantropical model revised by Chave et al.

243 (2014), which is derived from the equation in Chave et al. (2005), that is,

$$
B=0.0673 \times\left(\rho D^{2} H\right)^{0.976},
$$

where $D$ is the diameter in $\mathrm{cm}, H$ is the total height of the tree in $\mathrm{m}$, and $\rho$ is

the density of the wood. We obtained wood density values from the ForestPlots database (https://www.ForestPlots.net/). We chose this equation to calculate the

biomass because it is the most robust approach, given that it takes into consideration the diameter and height of each tree.

We developed a correlation matrix of the Kendall's tau values of the

environmental and forest structure variables mentioned above (Table S3). Multiple variables share similar source data, leading to high correlation amongst them, so we excluded those with greatest correlations $(r>0.7)$ to avoid repetition of largely redundant forest structure and climate variables (Tables S3 and S4). For all variables, the maximum values and the 95 percentiles were highly correlated; we included only the 95 percentile in order to avoid the influence of outliers. Finally, we excluded predictor variables that correlated poorly $(r<0.1)$ with the vegetation descriptors (Tables S3 and S4).

To verify possible differences among all forest plots in the structural

260 variables (95 percentiles of the $D, H$ and $H: D$, and mean $B$ ), we applied the Kruskal-

261 Wallis analysis of variance with the Dunnett post hoc test and a Bonferroni correction 262 (Zar 2010).

We evaluated the influence of habitat fragmentation and climatic variables 264 on forest structure using simple correlation and Generalised Linear Models (GLM). We 
265 also included in the models the forest type for each forest plot. Simple correlation

266 showed that, six seasonally flooded plots and two plots on anthropogenic black earth

267 were unduly influential, with extreme structure and covarying extreme climatic and 268 fragmentation conditions. To avoid these outliers driving the regional results we 269 excluded them from the GLM and correlation analyses described above. To build the GLM, we first standardised the data and removed the collinearities on the basis of Variance Inflation Factors (VIFs) of less than 10 (Quinn and Keough 2002). We conducted model selection using the Akaike's Information Criterion (AIC), with a model considered to be the best if it had the lowest AIC value

274 (Barton 2016). To access the spatial autocorrelation in the residuals for each model we used Moran's $I$. Here, no spatial dependence was detected among plots, indicating that the data were not spatially structured (Figure S5). Thus, we considered the plots as independent samples in our subsequent analyses.

We conducted the analyses using SAM 4.0 program (Rangel et al. 2010) and R 2.15.1 (R Core Team 2012). The applied R packages were vegan (Oksanen et al. 280 2016), spdep (Bivand et al. 2013), spacemakeR (Dray 2013), MuMIn (Barton 2016) and packfor (Dray et al. 2016). We adopted a 5\% significance level for all analyses and used 999 randomisations for the permutation methods.

284 Results

285 Forest structure

In general, the three open rainforest plots (FOA-01-03), a forest plot on

287 anthropogenic black earth (FTP-01), were significantly taller than the six seasonally 288 flooded forest plots (FSI-01-06), three seasonal semi-deciduous forest (FES-01-02-05) 
289 (Figure 2 and Table S6) and like the other 11 forest plots (FEP-01-07; FES-03-04 and 290 FTP-02-03). The $H: D$ ratio varied in a similar fashion to tree height, with the lowest

291 ratios (i.e., the lowest heights for a given diameter) being recorded in two of the 292 seasonally flooded forest plots (FSI-05 and FSI-06). Tree diameter and biomass did not 293 vary systematically among the plots, except for FSI-03, which had lower diameter and 294 biomass than the most of others plots (Figure 2).
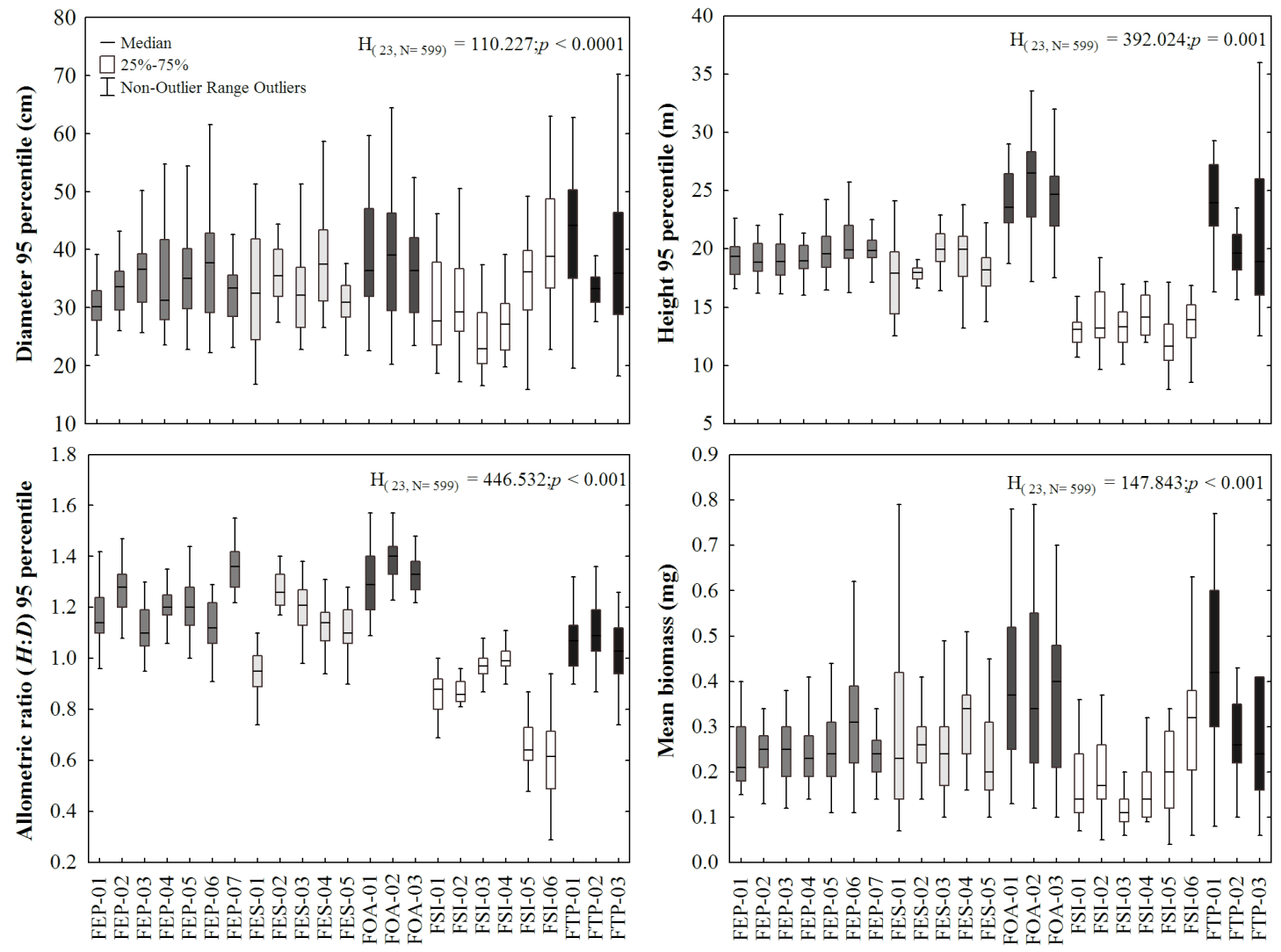

296 Figure 2. Variation in the vertical structure of forests at the southern Amazon border.

297 Box-plots show subplot-level values in each location, statistical comparisons are made

298 for among-forest analyses based on the non-parametric Kruskal-Wallis test $(\mathrm{H})$. The

299 complementary pair-wise analysis of forest structure is provided in Table S7. $\square=$ FTP

300 (seasonal evergreen forest on anthropogenic black earth), $\square=$ FOA (open rainforest), 
302 FSI (seasonally flooded forest).

303

304 Relationship between forest structure, fragmentation and climate variables

The structural variables were associated with the precipitation and with

306 fragment area and distance from the edge (Figure 3 and Table 2). Tree height, allometry

$307(H: D)$ and biomass all correlated positively with precipitation and fragment area (Figure

3). Tree height also correlated with the MCWD (Figure 3). Tree diameter did not

309 correlate with any of the variables. Additionally, the precipitation and MCWD

310 correlated positively with the fragment area $(P<0.05$; Kendal's $\tau=0.44$ and 0.60 ,

311 respectively).

312

313 Table 2. The relationship between environmental variables and forest structure, using

314 generalised linear models, of the southern Amazonia forests, Brazil. DE, distance to the

315 edge; PrecWM, precipitation of wettest month; $H: D$, allometric $H: D$ ratio; FES,

316 seasonal semi-deciduous forest-plots; FOA, open rainforest-plots. Significant effects $(P$

$317 \leq 0.05)$ are shown in bold type.

\begin{tabular}{ccccc}
\hline Factors & Estimate & Standard & $t$ & $P$ \\
\hline Height 95 percentile & & & & \\
Intercept & -0.276 & 0.109 & -2.531 & $\mathbf{0 . 0 0 3}$ \\
FES & -0.008 & 0.161 & -0.050 & 0.961 \\
FOA & 1.392 & 0.328 & 4.249 & $\mathbf{0 . 0 0 1}$ \\
PrecWM & 0.431 & 0.140 & 3.082 & $\mathbf{0 . 0 1 0}$ \\
\hline Diameter 95 percentile & & & & \\
Intercept & -0.356 & 0.290 & -1.228 & 0.243 \\
FES & 0.039 & 0.445 & 0.089 & 0.931 \\
FOA & 1.715 & 0.530 & 3.237 & $\mathbf{0 . 0 0 7}$ \\
\hline H:D 95 percentile & & & & \\
Intercept & $<0.001$ & 0.174 & $<0.001$ & 1.000 \\
DE & -0.785 & 0.302 & -2.597 & $\mathbf{0 . 0 2 3}$ \\
PrecWM & 1.260 & 0.302 & 4.167 & $\mathbf{0 . 0 0 1}$ \\
\hline
\end{tabular}




\begin{tabular}{|c|c|c|c|c|}
\hline \multicolumn{5}{|l|}{ Mean biomass } \\
\hline Intercept & -0.540 & 0.166 & -3.249 & 0.007 \\
\hline FES & 0.244 & 0.257 & 0.949 & 0.361 \\
\hline FOA & 2.291 & 0.303 & 7.555 & $<0.001$ \\
\hline
\end{tabular}
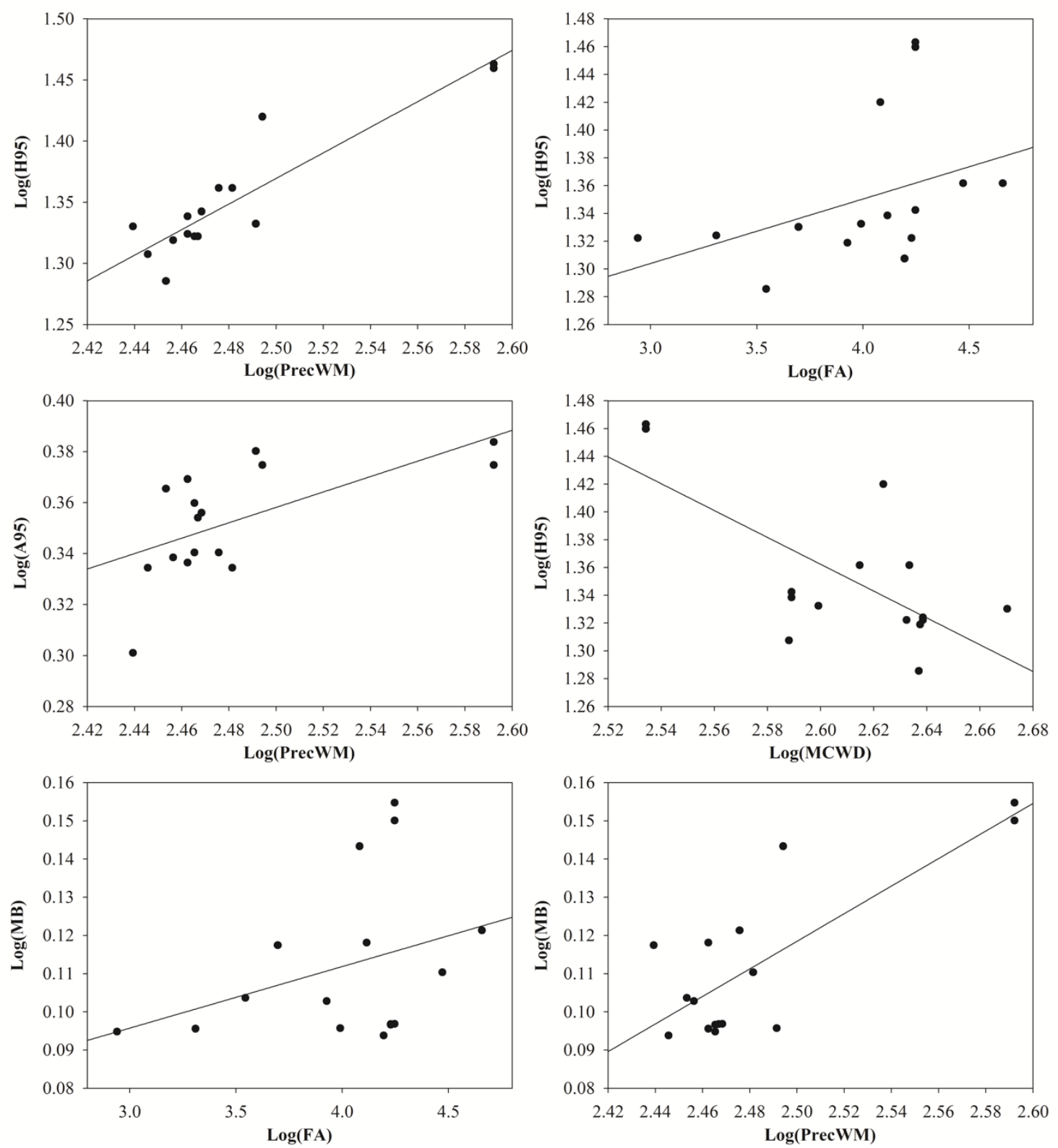

320 Figure 3 . Significant $(P \leq 0.05)$ relationships between forest structure and climatic and

321 fragmentation variables of the southern Amazon border forest plots. H95 = height 95

322 percentile, $\mathrm{A} 95=$ allometric ratio $(H: D) 95$ percentile, $\mathrm{MB}=$ mean biomass $(\mathrm{Mg}), \mathrm{FA}=$ 
323 fragment area (ha), PrecWM = precipitation of wettest month $(\mathrm{mm})$, MCWD $=$ 324 maximum climatological water deficit $(\mathrm{mm})$. and precipitation were most related to tree height (Table 2). Forest type was also a strongly related to tree diameter and biomass. Annual mean precipitation and distance from the edge were important factors for mean plot $H: D$ (Table 2). The percentage of forest cover around each plot was not selected in the best models and was not correlated with any forest structure variables. All plots presented more than $50 \%$ forest cover in surrounding landscapes. that each had similar (but inverse) effects on forest structure. Thus, all structural parameters affected positively by precipitation (Table 2) are affected negatively by moisture stress (MCWD) (Table S7).

\section{Discussion}

Our results show that the forests of the southern border zone of Amazonia vary remarkably in their structure, principally in terms of their tree height and tree height:diameter ratio. Most of the structural variation in these forests was statistically

342 related to fragment area and precipitation, supporting our overall expectations and 343 largely consistent with our hypotheses. Here we briefly first discuss this overall 344 variability and its potential ultimate drivers, before proceeding to discuss the results in more detail. 
349 fundamental determinant of the variability in forest structure here, principally because

350 drought events and seasonality may be more intense at the southern border in relation to

351 the core area of the Amazonas basin with evergreen non-seasonal rain forests (Lewis et al. 2011). In particular, water deficit may kill large trees (McIntyre et al. 2015), taller trees tend to be most affected by these conditions (Rowland et al. 2015). As these trees die and break-up or fall, large clearings are opened, favouring the establishment of species of different ecological groups (Lawton and Putz 1988). The frequent formation of clearings in these hyperdynamic transitional forests, as documented by Marimon et al. (2014), may thus also contribute to the structural variability found here. Finally, the forests of the southern border of the Amazon are located within a mosaic of vegetation types with many species typical of the adjacent biomes (Ratter et al. 1973), which may have a direct influence on the structural diversity of these forests.

\section{Seasonally flooded forest plots}

The lowest height and $H: D$ allometric ratio in the seasonally flooded forest

364 plots may be explained by their smaller fragment size and proximity to edges. These

365 factors as well as higher temperatures and lower precipitation (Table 1) may intensify 366 the fire effects. Fires in the wider grassland matrix can penetrate into forest fragments 367 and increase tree mortality, as observed in a recent study in these forest plots 368 (Maracahipes et al. 2014). It therefore appears likely that the combined effects of reduced fragment area and precipitation and higher temperatures, together with fire and 
370 its potential interactions with droughts (Brando et al. 2014), contribute to forest

371 structure here.

372

Response of the forest structure to the fragmentation and climate variables

Temperature appears to be an important factor determining the height of the trees worldwide, including potentially in tropical forests (Koch et al. 2004; Way and Oren 2010; Feldpausch et al. 2011; Lines et al. 2012; Pan et al. 2013), but here the absence of a clear statistical relationship between structure and temperature $(P>0.05$, Kendal's $\tau=0.31$ ) suggests it is not critical at the southern Amazon transition zone. Rather, in our study the greater forest heights, $H: D$ ratio and biomass that were observed with increasing precipitation suggest water supply is the dominant climate control on forest structure, and is consistent with some work elsewhere in the tropics (e.g. Alvarez et al. 2017), given especially that tropical plants tend to grow faster and taller as water is more available (Vlam et al. 2014; Givnish et al. 2014). In addition to apparent effects of annual rainfall, we also found that climatological water deficit was associated with reduced investment by the trees in height growth, consistent with the hypothesis that tree height is constrained by the availability of water (Ryan et al. 2004;

387 Givnish et al. 2014). A significant positive correlation was also found between 388 precipitation and tree height along a precipitation gradient in Australia, which Givnish 389 et al. (2014) related to the increase in leaf area and rates of photosynthesis with 390 increasing precipitation.

The negative correlation between the cumulative water deficit and tree height may be related to the mortality of the largest individuals during extreme drought events (Phillips et al. 2010). Such droughts have been directly observed in the study 
394 region in 2005, 2007, and 2010 (e.g. Brando et al. 2014), and these have indeed tended

395 to kill larger trees (Phillips et al. 2010; Feldpausch et al. 2016), as is often the case with

396 droughts in other tropical forests (Bennett et al. 2015). In Amazonia, recent strong

397 droughts appear also to be a major cause of the recent basin-wide increase in tree

398 mortality rates (Phillips et al. 2009; Brienen et al. 2015). In the near future, more

399 frequent extreme droughts, especially if combined with warming of the Amazon region

400 and thermal peaks in El Niño events such as in 2015-16 (Jiménez-Muñoz et al. 2016),

401 may therefore have profound implications for the forest structure of the southern

402 Amazon border, located as they are in a region that is already naturally close to their

403 distributional and hydraulic limits. In this scenario, large trees are more susceptible to

404 damage to the xylem, which can ultimately result in the death of the plant (e.g. McIntyre

405 et al. 2015) and eventually lead to forests of lower stature (McDowell et al. 2008;

406 Rowland et al. 2015). Trees being smaller in drier areas with greater water deficiency is

407 directly be related to conservative modifications in the hydraulic structure of the plants

408 under hydrological stress to avoid embolism (e.g. Lines et al. 2012, Claeys and Inzé

409 2013). Thus, as have recently argued in both tropical and temperate zone contexts (e.g.

410 Stegen et al. 2011; Banin et al. 2012; McIntyre et al. 2015) it is likely that trees in

411 forests subject either to more extreme climatic events, or to more disturbance (including

412 seasonally flooded habitats), or both, will in general tend to be shorter at a given

413 diameter in order to avoid risks of hydraulic and/or mechanical failure, whereas trees in

414 forests with high rainfall, such as our FOA-01 and FOA-02, will have greater heights 415 and hence greater biomass.

416 Besides the correlation with the climatic variables, both height and the

417 biomass of trees were positively correlated with fragment area. This result may be 
418 related to the incidence of wind in smaller fragments which have a higher proportion of

419 forest edge (D'Angelo et al. 2004; Laurance 2004; Haddad et al. 2015). These

420 disturbances are known to be able to generate high mortality, especially of the tallest

421 trees (Laurance et al. 2000; Laurance 2004), and consequently in our dataset such edge-

422 generated disturbances may have affected the height and biomass of trees. Elsewhere,

423 local climatic changes as a result of fragmentation can reduce the density and diversity

424 of species (Mantyka-Pringle et al. 2012). Such effects can also increase the 425 susceptibility of fragmented forest structure and their biota to fire (Laurance and

426 Williamson 2001; Laurance 2004). In the southern Amazon region, these different 427 effects are all likely to be relevant, but clearly further analysis is needed, including long428 term monitoring evaluation of the climatic and dynamic processes in these forests.

\section{Conclusions}

Our analysis across different locations, spanning a large part of the southern

432 Amazon zone, suggests climate sensitivity in forest structure here. Climate change, and 433 especially any reduction in annual or seasonal precipitation, is thus likely to have a 434 significant effect on the forest structure in the southern border of the Amazon. 435 Secondly, our results also suggest that the effects of reduction in the annual 436 precipitation may be further exacerbated in smaller fragments. This suggests that habitat 437 fragmentation may intensify the negative effects of climate change and burning in 438 forests in the southern Amazon border, resulting in a substantial risk of increases in tree 439 mortality. Given the likely susceptibility of the remaining southern Amazon border 440 forests to environmental change, strong conservation strategies are urgently needed to 
441 guarantee the persistence of these habitats, especially for the smaller fragments and 442 those close to agricultural frontiers.

443

\section{Acknowledgements}

We are grateful to the team of the Laboratório de Ecologia Vegetal - Plant 446 Ecology Laboratory at the UNEMAT campus in Nova Xavantina, especially to 447 Henrique Augusto Mews, Nayane Cristina Prestes, Ana Paula Gomes da Silva, Laís 448 Fernandes de Souza Neves, Mônica Forsthofer and Leonardo Maracahipes, for help in 449 collecting field data. We also thank the National Council for Scientific and 450 Technological Development $(\mathrm{CNPq})$ for financial support of the projects PELD 451 "Cerrado-Amazon Forest Transition: ecological and socio-environmental bases for 452 Conservation" (stage II) - process nr. 403725/2012-7), PVE “special visiting researcher" 453 (401279/2014-6), PPBIO "Phytogeography of the Amazon-Cerrado Transition Zone" 454 (457602/2012-0) and FAPEMAT - Fundação de Amparo à Pesquisa do Estado de Mato 455 Grosso (164131/2013). We also thank CNPq for research productivity grants to B.S. 456 Marimon and B.H. Marimon Junior, a post-doctoral scholarship to D. Nogueira, and 457 international doctoral grants to S.M.A. Reis and P.S. Morandi. We are also grateful to 458 CAPES and FAPEMAT for scholarships to S.M.A. Reis, P.S. Morandi, F. Elias, E.A. 459 Oliveira and E.C. Neves.

460

$461 \quad$ Notes on contributors

462 Simone Matias Reis is a Ph.D. student focussing on the effects of biotic and abiotic 463 factors on forest structure in the southern border of Amazonia. 
464 Beatriz Schwantes Marimon is professor and an ecologist with experience in working

465 with structure and dynamics of different vegetation types of the southern Amazon

466 boundaries in Central Brazil. Her current work focuses on ecology and management of

467 forests in the transition zone between Cerrado and Amazon forest biomes, and currently

468 has great interest in understanding changes in tropical plants communities as a result of

469 climate change.

470 Ben Hur Marimon-Junior is professor. He has experience in forest ecology, studying

471 biogeochemical cycles, carbon stocks, pyrogenic carbon in mineral nutrition of plants,

472 biodiversity and ecosystem functions. His current work focuses on understanding

473 changes in tropical plants communities as a result of climate change.

474 Paulo S. Morandi is a Ph.D. student focussing on structural patterns, diversity and 475 distribution of species under the effect of environmental variables and vegetation 476 succession in the Amazon-Cerrado transition.

477 Edmar Almeida de Oliveira is a Ph.D. student focussing on historical effect of soil

478 disturbance and pyrogenic carbon on the composition and structure of forests in

479 southern Amazonia.

480 Fernando Elias is a Ph.D. student focussing on the role of climate, land management

481 and landscape on the resilience of secondary forests in the Amazon.

482 Eder Carvalho das Neves is M.Sc. student focussing on the physiology of forests in the 483 Amazon-Cerrado transition.

484 Bianca de Oliveira is a biologist and conducted her master's research on nutrient 485 cycling in the Amazonia-Cerrado transition.

486 Denis Nogueira is a post-doctoral researcher focusing on forest dynamics of the 487 Amazon-Cerrado transition in Mato Grosso. 
488 Ricardo Keichi Umetsu is a lecturer. He has experience in environmental planning with

489 emphasis on water resources, hydrographic basins, hydrogeochemistry of streams, plant

490 ecology and landscape.

491 Ted R. Feldpausch is a lecturer in tropical ecology. His research focuses on the ecology

492 and effects of global change on tropical forests.

493 Oliver L. Phillips is professor of tropical ecology. He leads the RAINFOR network of 494 scientists in Amazonian forests.

495

\section{References}

497 Alencar A, Nepstad DC, McGrath D, Moutinho P, Pacheco P, Diaz MDCV, Soares

498 Filho B. 2004. Desmatamento na Amazônia: indo além da "emergência crônica". 499 Intituto de Pesquisa Ambiental da Amazônia, Belém.

500 Alencar AA, Brando PM, Asner GP, Putz FE. 2015. Landscape fragmentation, severe

501 drought, and the new Amazon forest fire regime. Ecological Applications 25: 1493$502 \quad 1505$.

503 Alvares CA, Stape JL, Sentelhas PC, de Moraes G, Leonardo J, Sparovek G. 2013. 504 Köppen's climate classification map for Brazil. Meteorologische Zeitschrift 22: 711$505 \quad 728$

506 Álvarez-Dávila E, Cayuela L, González-Caro S, Aldana AM, Stevenson PR, Phillips O, 507 Cogollo A, Peñuela MC, von Hildebrand P, Jiménez E, et al. 2017. Forest biomass 508 density across large climate gradients in northern South America is related to water 509 availability but not with temperature. PLOS ONE 12:e171072. 
510 Angiosperm Phylogeny Group. 2009. An update of the angiosperm Phylogeny group

511 classification for the orders and families of flowering plants: APG III. Bot J Linn Soc $512 \quad 161: 105-121$.

513 Aragao LEO, Malhi Y, Roman-Cuesta RM, Saatchi S, Anderson LO, Shimabukuro YE.

514 2007. Spatial patterns and fire response of recent Amazonian droughts. Geophysical $515 \quad$ Research Letters 34.

516 Aragão LE. 2012. Environmental science: The rainforest's water pump. Nature 489: $517 \quad 217-218$.

518 Atkin OK, Bloomfield KJ, Reich PB, Tjoelker MG, Asner GP, Bonal D, Bönisch G, 519 Bradford MG, Cernusak LA, Cosio EG, et al. 2015. Global variability in leaf 520 respiration in relation to climate, plant functional types and leaf traits. New $521 \quad$ Phytologist 206:614-636.

522 Banin L, Feldpausch TR, Phillips OL, Baker TR, Lloyd J, Affum-Baffoe K, Arets 523 EJMM, Berry NJ, Bradford M, Brienen RJW, et al. 2012. What controls tropical 524 forest architecture? Testing environmental, structural and floristic drivers. Global $525 \quad$ Ecology and Biogeography 21: 1179-1190.

526 Banin LF, Phillips OL, Lewis SL. 2015. Tropical Forests. Routledge Handbook of $527 \quad$ Forest Ecology 5: 56-75.

528 Barton K. 2016. MuMIn: Multi-model inference. R package; [cited 2017 Fev 20]. 529 Available from: https://cran.r-project.org/web/packages/MuMIn/MuMIn.pdf.

530 Bennett AC, McDowell NG, Allen CD, Anderson-Teixeira KJ. 2015. Larger trees suffer 531 most during drought in forests worldwide. Nature plants 1: 15139. 
532 Bivand RS, Hauke J, Kossowski T. 2013. Computing the Jacobian in Gaussian spatial 533 autoregressive models: An illustrated comparison of available methods. 534 Geographical Analysis 45: 150-179.

535 Boisier JP, Ciais P, Ducharne A, Guimberteau M. 2015. Projected strengthening of 536 Amazonian dry season by constrained climate model simulations. Nature Climate 537 Change 5: 656-660.

538 Brando PM, Balch JK, Nepstad DC, Morton DC, Putz FE, Coe MT, Silvério D, Macedo

539 MN, Davidson EA, Nóbrega CC, et al. 2014. Abrupt increases in Amazonian tree 540 mortality due to drought-fire interactions. Proceedings of the National Academy of $541 \quad$ Sciences 111: 6347-6352.

542 Brienen RJW, Phillips OL, Feldpausch TR, Gloor E, Baker TR, Lloyd J, Lopez543 Gonzalez G, Monteagudo-Mendoza A, Malhi Y, Lewis SL, et al. 2015. Long-term 544 decline of the Amazon carbon sink. Nature 519: 344-348.

545 Chaplin-Kramer R, Ramler I, Sharp R, Haddad NM, Gerber JS, West PC, Mandle L, 546 Engstrom P, Baccini A, Sim S, et al. 2015. Degradation in carbon stocks near $547 \quad$ tropical forest edges. Nature communications 6.

548 Chave J, Andalo C, Brown S, Cairns MA, Chambers JQ, Eamus D, Folster H, Fromard 549 F, Higuchi N, Kira T, et al. 2005. Tree allometry and improved estimation of carbon $550 \quad$ stocks and balance in tropical forests. Oecologia 145: 87-99.

551 Chave J, Réjou-Méchain M, Búrquez A, Chidumayo E, Colgan MS, Delitti WB, Duque 552 A, Eid T, Fearnside PM, Goodman RC, et al. 2014. Improved allometric models to 553 estimate the aboveground biomass of tropical trees. Global change biology 20: 31775543190. 
555 Claeys H, Inzé D. 2013. The agony of choice: how plants balance growth and survival 556 under water-limiting conditions. Plant Physiology 162: 1768-1779.

557 Cox PM, Betts RA, Jones CD, Spall SA, Totterdell IJ. 2000. Acceleration of global 558 warming due to carbon-cycle feedbacks in a coupled climate model. Nature 408: $559 \quad 184-187$.

560 D'Angelo SA, Andrade ACS, Laurance SG, Laurance WF, Mesquita RCG. 2004. 561 Inferred causes of tree mortality in fragmented and intact Amazonian forests. Journal 562 of Tropical Ecology 20: 243-246.

563 Doughty CE, Metcalfe DB, Girardin CAJ, Amézquita FF, Cabrera DG, Huasco WH, 564 Silva-Espejo JE, Araujo-Murakami A, da Costa MC, Rocha W, et al. 2015. Drought 565 impact on forest carbon dynamics and fluxes in Amazonia. Nature 519: 78-82.

566 Dray S. 2013. spacemakeR: Spatial modelling. R package version 0.0-5/r113. https:/R$567 \quad$ Forge.R-project.org/projects/sedar/

568 Dray S, Legendre P, Blanchet G. 2016. packfor: Forward Selection with permutation 569 (Canoco p. 46). $\mathrm{R}$ package version 0.0-8/r136. https://R-Forge.R$570 \quad$ project.org/projects/sedar/

571 Feldpausch TR, Banin L, Phillips OL, Baker TR, Lewis SL, Quesada CA, Affum572 Baffoe K, Arets EJMM, Berry NJ, Bird M, et al. 2011. Height-diameter allometry of $573 \quad$ tropical forest trees. Biogeosciences 8: 1081-1106.

574 Fahrig L. 2003. Effects of habitat fragmentation on biodiversity. Annual Review of 575 Ecology, Evolution, and Systematics 34: 487-515.

576 Feldpausch TR, Phillips OL, Brienen RJW, Gloor E, Lloyd J, Lopez-Gonzalez G, 577 Monteagudo-Mendoza A, Malhi Y, Alarcón A, Álvarez Dávila E, et al. 2016. 
578 Amazon forest response to repeated droughts. Global Biogeochemical Cycles 30: 1$579 \quad 19$.

580 Givnish TJ, Wong SC, Stuart-Williams H, Holloway-Phillips M, Farquhar GD. 2014.

581 Determinants of maximum tree height in Eucalyptus species along a rainfall gradient 582 in Victoria, Australia. Ecology 95: 2991-3007.

583 Gloor M, Barichivich J, Ziv G, Brienen R, Schöngart J, Peylin P, Cintra BBL, 584 Feldpausch T, Phillips O, Baker J. 2015. Recent Amazon climate as background for 585 possible ongoing and future changes of Amazon humid forests. Global 586 Biogeochemical Cycles 29: 1384-1399.

587 Haddad NM, Brudvig LA, Clobert J, Davies KF, Gonzalez A, Holt RD, Lovejoy TE, 588 Sexton JO, Austin MP, Collins CD, et al. 2015. Habitat fragmentation and its lasting $589 \quad$ impact on Earth's ecosystems. Science Advances 1: e1500052.

590 Heskel MA, O’Sullivan OS, Reich PB, Tjoelker MG, Weerasinghe LK, Penillard A, 591 Egerton JJ, Creek D, Bloomfield KJ, Xiang J, et al. 2016. Convergence in the 592 temperature response of leaf respiration across biomes and plant functional types. 593 Proceedings of the National Academy of Sciences 113: 3832-3837.

594 Hijmans RJ, Cameron SE, Parra JL, Jones PG, Jarvis A. 2005. Very high resolution 595 interpolated climate surfaces for global land areas. International journal of $596 \quad$ climatology 25: 1965-1978.

597 IBGE - Instituto Brasileiro de Geografia e Estatística. 2004. Área territorial brasileira; 598 [cited 2017 Jun 25]. Available from: http://www.ibge.gov.br/

599 INPE - Instituto Nacional de Pesquisas Espaciais. 2017. Coordenação geral de 600 observação da terra. Projeto PRODES: monitoramento da Floresta Amazônica 
601 Brasileira por Satélite; [cited 2017 Jun 29]. Available from:

602 http://www.obt.inpe.br/prodes/index.php

603 IPCC - Intergovernmental Panel on Climate Change. 2015. Climate change 2014:

604 mitigation of climate change. Cambridge: Cambridge University Press.

605 Jiménez-Muñoz JC, Mattar C, Barichivich J, Santamaría-Artigas A, Takahashi K, Malhi

606 Y, Sobrino JA, van der Schrier G. 2016. Record-breaking warming and extreme

607 drought in the Amazon rainforest during the course of El Niño 2015-2016. Scientific

$608 \quad$ Reports 6: 33130.

609 Jiménez-Muñoz JC, Sobrino JA, Mattar C, Malhi Y. 2013. Spatial and temporal patterns

610 of the recent warming of the Amazon forest. Journal of Geophysical Research:

$611 \quad$ Atmospheres 118: 5204-5215.

612 Kark S, van Rensburg BJ. 2006. Ecotones: marginal or central areas of transition? Israel

613 Journal of Ecology \& Evolution 52: 29-53.

614 Kark S, Hadany L, Safriel UN, Noy-Meir I, Eldredge N, Tabarroni C, Randi E. 2008.

615 How does genetic diversity change towards the range periphery? Evolutionary $616 \quad$ Ecology Research 10: 391-414.

617 Koch GW, Sillett SC, Jennings GM, Davis SD. 2004. The limits to tree height. Nature $618 \quad 428: 851-854$.

619 Laurance WF, Ferreira LV, Rankin-de Merona JM, Laurance SG. 1998. Rain forest 620 fragmentation and the dynamics of Amazonian tree communities. Ecology 79: 20326212040.

622 Laurance WF, Laurance SG, Ferreira LV, Merona JMR, Gascon C. 1997. Biomass 623 Collapse in Amazonian Forest Fragments. Science 278: 1117-1118. 
624 Laurance WF, Delamônica P, Laurance SG, Vasconcelos HL, Lovejoy TE. 2000.

625 Conservation: rainforest fragmentation kills big trees. Nature 404: 836-836.

626 Laurance WF, Williamson GB. 2001. Positive feedbacks among forest fragmentation,

627 drought, and climate change in the Amazon. Conservation Biology 15: 1529-1535.

628 Laurance WF. 2004. Forest-climate interactions in fragmented tropical landscapes.

629 Philosophical Transactions of the Royal Society of London B: Biological Sciences $630 \quad 359: 345-352$.

631 Lawton RO, Putz FE. 1988. Natural disturbance and gap-phase regeneration in a 632 wind-exposed tropical cloud forest. Ecology 69: 764-777.

633 Lewis SL, Brando PM, Phillips OL, van der Heijden GM, Nepstad D. 2011. The 2010 634 amazon drought. Science 331: 554-554

635 Lewis SL, Sonké B, Sunderland T, Begne SK, Lopez-Gonzalez G, van der Heijden, 636 GM, Phillips OL, Affum-Baffoe K, Baker TR, Banin L, et al. 2013. Above-ground 637 biomass and structure of 260 African tropical forests. Philosophical Transactions of $638 \quad$ the Royal Society B 368: 20120295.

639 Lines ER, Zavala MA, Purves DW, Coomes DA. 2012. Predictable changes in 640 aboveground allometry of trees along gradients of temperature, aridity and 641 competition. Global Ecology and Biogeography 21: 1017-1028.

642 Lista de Espécies da Flora do Brasil. 2016. Jardim Botânico do Rio de Janeiro; [cited 6432016 Jul 17]. Available from: http://floradobrasil.jbrj.gov.br/2016

644 Lloyd J, Farquhar GD. 2008. Effects of rising temperatures and $\left[\mathrm{CO}_{2}\right]$ on the 645 physiology of tropical forest trees. Philosophical Transactions of the Royal Society 646 B: Biological Sciences 363: 1811-1817. 
647 Lopez-Gonzalez G, Lewis SL, Burkitt M, Phillips OL. 2011. ForestPlots.net: a web 648 application and research tool to manage and analyse tropical forest plot data. Journal 649 of Vegetation Science 22: 610-613.

650 Mantyka-pringle CS, Martin TG, Rhodes JR. 2012. Interactions between climate and 651 habitat loss effects on biodiversity: a systematic review and meta-analysis. Global 652 Change Biology 18: 1239-1252.

653 Maracahipes L, Marimon BS, Lenza E, Marimon-Junior BH, de Oliveira EA, Mews 654 HA, Gomes L, Feldpausch TR. 2014. Post-fire dynamics of woody vegetation in 655 seasonally flooded forests (impucas) in the Cerrado-Amazonian Forest transition 656 zone. Flora-Morphology, Distribution, Functional Ecology of Plants 209: 260-270.

657 Marengo JA, Tomasella J, Alves LM, Soares WR, Rodrigues DA. 2011. The drought 658800 of 2010 in the context of historical droughts in the Amazon region. Geophysical $659 \quad$ Research Letters 38.

660 Marimon BS, Marimon-Junior BH, Feldpausch TR, Oliveira-Santos C, Mews HA, 661 Lopez-Gonzalez G, Lloyd J, Franczak D, de Oliveira EA, Maracahipes L, et al. 2014. 662 Disequilibrium and hyperdynamic tree turnover at the forest-cerrado transition zone 663 in southern Amazonia. Plant Ecology \& Diversity 7: 281-292.

664 McDowell N, Pockman T, Allen CD, Breshears DD, Cobb N, Kolb T, Plaut J, Sperry J, 665 West A, Williams DG. 2008. Mechanisms of plant survival and mortality during 666 drought: why do some plants survive while others succumb to drought? New $667 \quad$ Phytologist 178: 719-739.

668 McGarigal K, Cushman S. 2002. Comparative evaluation of experimental approaches to 669 the study of habitat fragmentation effects. Ecological Applications 12: 335-345. 
670 McIntyre PJ, Thorne JH, Dolanc CR, Flint AL, Flint LE, Kelly M, Ackerly DD. 2015. 671 Twentieth-century shifts in forest structure in California: Denser forests, smaller 672 trees, and increased dominance of oaks. Proceedings of the National Academy of $673 \quad$ Sciences 112: 1458-1463.

674 NASA 2012. TRMM 3B43(7): Monthly $0.25 \times 0.25$ degree merged TRMM and other 675 sources estimates, 676 http://disc.sci.gsfc.nasa.gov/precipitation/documentation/TRMM_README/TRMM 677 _3B43_readme.shtml, edited, NASA Distrib. Active Arch. Cent., Goddard Space 678 Flight Cent. Earth Sci., Greenbelt, Md.

679 Nogueira EM, Fearnside PM, Nelson BW, Barbosa RI, Keizer EWH. 2008. Estimates 680 of forest biomass in the Brazilian Amazon: new allometric equations and adjustments 681 to biomass from wood-volume inventories. Forest Ecology and Management 256: $682 \quad 1853-1857$.

683 Oksanen J, Blanchet FG, Friendly M, Kindt R, Legendre P, McGlinn D, Minchin PR, 684 O'Hara RB, Simpson GL, Solymos P, et al. 2016. vegan: Community Ecology 685 Package. R package version 2.4-0. https://CRAN.R-project.org/package=vegan 686 Pan Y, Birdsey RA, Phillips OL, Jackson RB. 2013. The structure, distribution, and 687 biomass of the world's forests. Annual Review of Ecology, Evolution, and 688 Systematics 44: 593-622.

689 Phillips OL, Aragão LEOC, Lewis SL, Fisher JB, Lloyd J, López-González G, Malhi Y, 690 Monteagudo A, Peacock J, Quesada CA, et al. 2009. Drought Sensitivity of the 691 Amazon Rainforest. Science 323:1344-1347. 
692 Phillips OL, Van Der Heijden G, Lewis SL, López-González G, Aragão LE, Lloyd J,

693 Malhi Y, Monteagudo A, Almeida S, Dávila EA, et al. 2010. Drought-mortality 694 relationships for tropical forests. New Phytologist 187: 631-646.

695 Quinn GP, Keough PR. 2002. Experimental design and data analysis for biologists. 696 Cambridge: Cambridge University Press.

697 Rangel TF, Diniz-Filho JAF, Bini LM. 2010. SAM: a comprehensive application for 698 spatial analysis in macroecology. Ecography 33: 46-50.

699 Ratter JA, Richards PW, Argent G, Gifford DR. 1973. Observations on the vegetation 700 of the northeastern Mato Grosso. I. The woody vegetation types of the Xavantina701 Cachimbo Expedition area. Philosophical Transactions of the Royal Society of $702 \quad$ London B 266: 449-492.

703 Rocha-Santos L, Pessoa MS, Cassano CR, Talora DC, Orihuela RL, Mariano-Neto E, 704 Morante-Filho JC, Faria D, Cazetta E. 2016. The shrinkage of a forest: landscape705 scale deforestation leading to overall changes in local forest structure. Biological 706 Conservation 196: 1-9.

707 Rowland L, da Costa ACL, Galbraith DR, Oliveira RS, Binks OJ, Oliveira AAR, Pullen 708 AM, Doughty CE, Metcalfe DB, Vasconcelos SS, et al. 2015. Death from drought in 709 tropical forests is triggered by hydraulics not carbon starvation. Nature 528: 119$710 \quad 122$.

711 Ryan MG, Binkley D, Fownes JH, Giardina CP, Senock RS. 2004. An experimental test 712 of the causes of forest growth decline with stand age. Ecological Monographs 74: $713 \quad 393-414$.

714 Saatchi SS, Harris NL, Brown S, Lefsky M, Mitchard ET, Salas W, Zuttaa BR, 715 Buermannb W, Lewis SL, Hagenf S, et al. 2011. Benchmark map of forest carbon 
716 stocks in tropical regions across three continents. Proceedings of the National 717 Academy of Sciences 108: 9899-9904.

718 Safriel UN, Volis S, Kark S. 1994. Core and peripheral populations and global climate 719 change. Israel Journal of Plant Sciences 42: 331-345.

720 Silvério DV, Brando PM, Macedo MN, Beck PS, Bustamante M, Coe MT. 2015. 721 Agricultural expansion dominates climate changes in southeastern Amazonia: the 722 overlooked non-GHG forcing. Environmental Research Letters 10: 104015.

723

Stegen JC, Swenson NG, Enquist BJ, White EP, Phillips OL, Jørgensen PM, Weiser 724 MD, Monteagudo Mendoza A, Núñez Vargas P. 2011. Variation in above-ground forest biomass across broad climatic gradients. Global Ecology and Biogeography 20: 744-754.

727

Vlam M, Baker PJ, Bunyavejchewin S, Zuidema PA. 2014. Temperature and rainfall 728 strongly drive temporal growth variation in Asian tropical forest trees. Oecologia 174: 1449-1461.

730 Way DA, Oren R. 2010. Differential responses to changes in growth temperature 731 between trees from different functional groups and biomes: a review and synthesis of 732 data. Tree physiology 30: 669-688.

733 Worbes M. 1999. Annual growth rings, rainfall-dependent growth and long-term growth 734 patterns of tropical trees from the Caparo Forest Reserve in Venezuela. Journal of 735 Ecology 87: 391-403.

736 Zar JH. 2010. Biostatistical analysis. New Jersey: Prentice Hall. 


\section{Supplementary material}

Table S1. Environmental predictors and vegetation descriptors used in the analyses.

\begin{tabular}{|c|c|c|c|}
\hline Variable abbreviation & Environmental predictors & Variable abbreviation & Vegetation descriptors \\
\hline FA & Fragment area (ha) & MIH & Minimum height (m) \\
\hline $\mathrm{DE}$ & Distance to the forest edge $(\mathrm{m})$ & MAH & Maximum height (m) \\
\hline $\mathrm{FC}$ & Forest cover $(\%)$ & MH & Median height (m) \\
\hline MCWD & Maximum climatological water deficit (mm) & H95 & Height 95 percentile (m) \\
\hline Temp & Mean annual temperature $\left({ }^{\circ} \mathrm{C}\right)$ & $\mathrm{LH}$ & Weighted Lorey's height \\
\hline TempMDR & Mean diurnal range $\left({ }^{\circ} \mathrm{C}\right)$ & MD & Median diameter $(\mathrm{cm})$ \\
\hline Isoter & Isothermality $\left({ }^{\circ} \mathrm{C}\right)$ & MAD & Maximum diameter $(\mathrm{cm})$ \\
\hline TempSaz & Temperature seasonality (standard deviation $* 100)\left({ }^{\circ} \mathrm{C}\right)$ & D95 & Diameter 95 percentile $(\mathrm{cm})$ \\
\hline TempWM & Max temperature of warmest month $\left({ }^{\circ} \mathrm{C}\right)$ & MIA & Minimum allometric ratio $(H: D)$ \\
\hline TempCM & Min temperature of coldest month $\left({ }^{\circ} \mathrm{C}\right)$ & MAA & Maximum allometric ratio $(H: D)$ \\
\hline TempAR & Temperature annual range $\left({ }^{\circ} \mathrm{C}\right)$ TempWM - TempCM & MA & Median allometric ratio $(H: D)$ \\
\hline TempWeQ & Mean temperature of wettest quarter $\left({ }^{\circ} \mathrm{C}\right)$ & A95 & Allometric ratio $(H: D) 95$ percentile \\
\hline TempDQ & Mean temperature of driest quarter $\left({ }^{\circ} \mathrm{C}\right)$ & MB & Mean biomass ( $\mathrm{Mg} \mathrm{ha})$ \\
\hline TempWaQ & Mean temperature of warmest quarter $\left({ }^{\circ} \mathrm{C}\right)$ & MEB & Median biomass ( $\mathrm{Mg}$ ha) \\
\hline TempCQ & Mean temperature of coldest quarter $\left({ }^{\circ} \mathrm{C}\right)$ & $\mathrm{TB}$ & Total biomass (Mg ha) \\
\hline Prec & Total annual precipitation $(\mathrm{mm})$ & & \\
\hline PrecWM & Precipitation of wettest month (mm) & - & - \\
\hline PrecDM & Precipitation of driest month (mm) & - & - \\
\hline PrecSaz & Precipitation seasonality (Coefficient of Variation) $(\mathrm{mm})$ & - & - \\
\hline PrecWeQ & Precipitation of wettest quarter $(\mathrm{mm})$ & - & - \\
\hline PrecDQ & Precipitation of driest quarter (mm) & - & - \\
\hline PrecWaQ & Precipitation of warmest quarter (mm) & - & - \\
\hline PrecCQ & Precipitation of coldest quarter (mm) & - & - \\
\hline
\end{tabular}




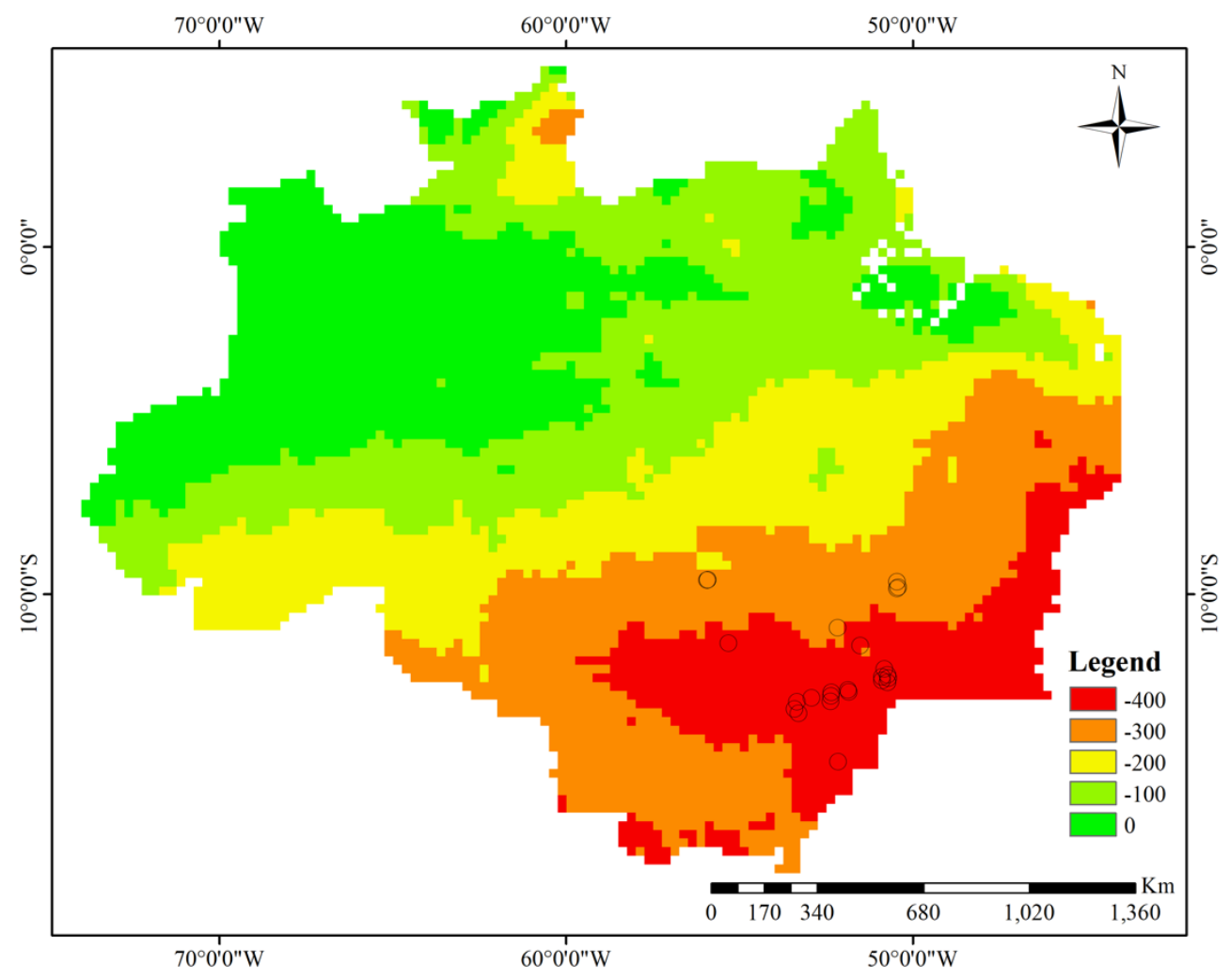

Figure S2. Mean of the maximum climatological water deficit (MCWD) (mm) in the Amazon basin between 1999 and 2011, in the context of the rest of Amazonia. Circles show the forest plots localization. 
Table S3. Kendall tau correlations of the all 37 environmental and forest structure variables obtained to the forests of the southern Amazon border. $\mathrm{FA}=$ fragment area (ha), $\mathrm{DE}=$ distance to the edge $(\mathrm{m}), \mathrm{MCWD}=$ maximum climatological water deficit $(\mathrm{mm})$, Temp $=\mathrm{mean}$ annual temperature $\left({ }^{\circ} \mathrm{C}\right)$, TempMDR $=$ Mean diurnal range $\left({ }^{\circ} \mathrm{C}\right)$, Isoter $=$ Isothermality $\left({ }^{\circ} \mathrm{C}\right)$, TempSaz $=$ Temperature seasonality $($ standard deviation *100) $\left({ }^{\circ} \mathrm{C}\right)$, TempWM $=$ Max temperature of warmest month $\left({ }^{\circ} \mathrm{C}\right)$, TempCM $=$ Min temperature of coldest month $\left({ }^{\circ} \mathrm{C}\right)$, TempAR $=$ Temperature annual range $\left({ }^{\circ} \mathrm{C}\right)$ TempWM - TempCM, TempWeQ $=$ Mean temperature of wettest quarter $\left({ }^{\circ} \mathrm{C}\right)$, TempDQ $=\mathrm{Mean}$ temperature of driest quarter $\left({ }^{\circ} \mathrm{C}\right)$, TempWaQ $=$ Mean temperature of warmest quarter $\left({ }^{\circ} \mathrm{C}\right)$, TempCQ $=$ Mean temperature of coldest quarter $\left({ }^{\circ} \mathrm{C}\right)$, Prec $=$ Total annual precipitation $(\mathrm{mm})$, PrecWM $=$ Precipitation of wettest month $(\mathrm{mm})$, PrecDM = Precipitation of driest month $(\mathrm{mm})$, PrecSaz $=$ Precipitation seasonality (Coefficient of Variation) $(\mathrm{mm})$, PrecWeQ $=$ Precipitation of wettest quarter $(\mathrm{mm})$, PrecDQ $=$ Precipitation of driest quarter $(\mathrm{mm})$, PrecWaQ $=$ Precipitation of warmest quarter $(\mathrm{mm})$, PrecCQ $=$ Precipitation of coldest quarter (mm), MIH = Minimum height (m), MAH = Maximum height (m), MH = Median height (m), H95= Height 95 percentile (m), LH $=$ Weighted Lorey's height, MD = Median diameter $(\mathrm{cm})$, MAD $=$ Maximum diameter $(\mathrm{cm})$, D95 = Diameter 95 percentile $(\mathrm{cm})$, MIA = Minimum allometric ratio $(H: D)$, MAA = Maximum allometric ratio $(H: D)$, MA $=$ Median allometric ratio $(H: D)$, A95 = Allometric ratio $(H: D) 95$ percentile, $\mathrm{MB}=$ Mean biomass (Mg ha), $\mathrm{MEB}=$ Median biomass (Mg ha), $\mathrm{TB}=$ Total biomass (Mg ha). Significant correlations $(p \leq 0.05)$ are shown in bold type. 


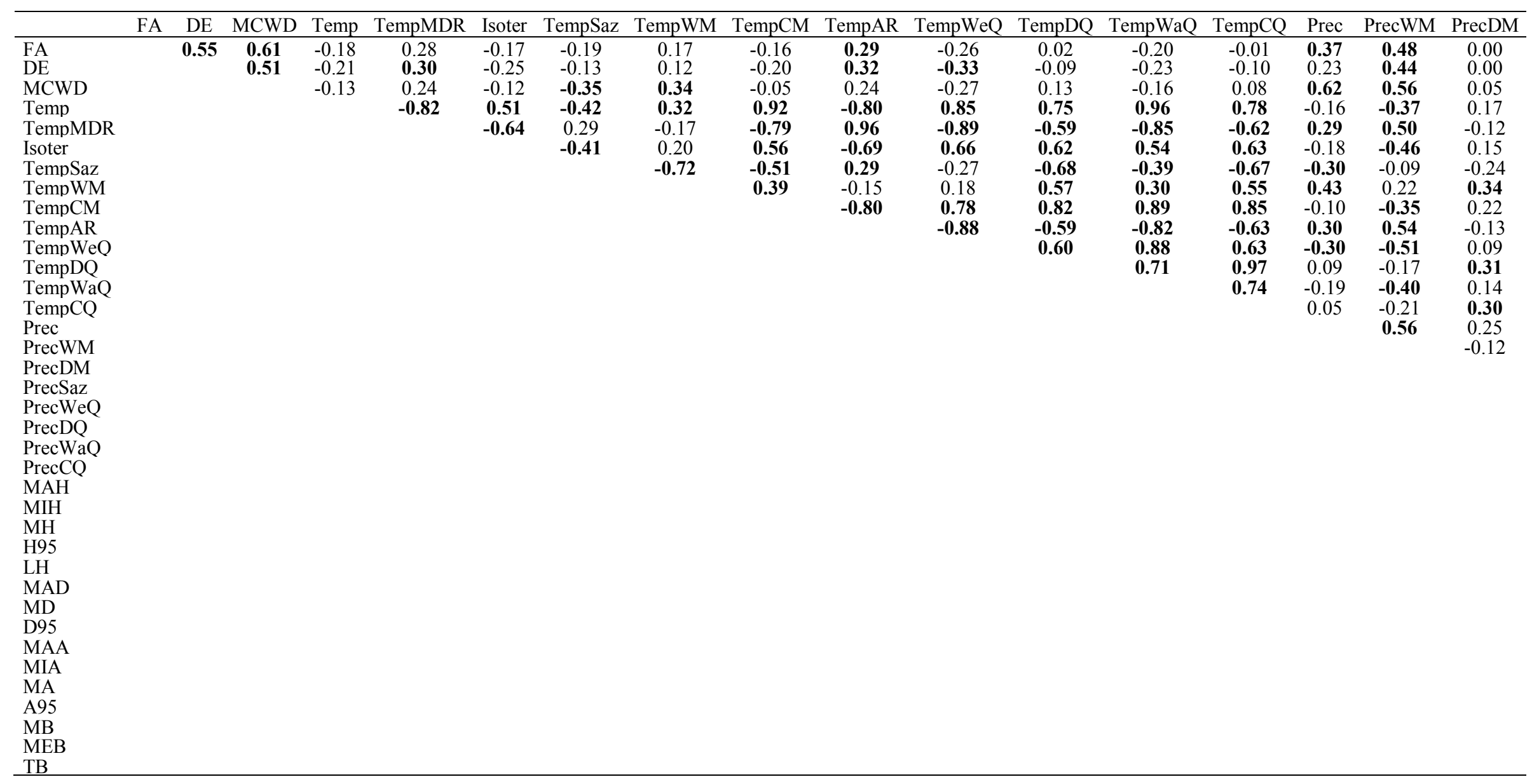


Continuation...

\begin{tabular}{|c|c|c|c|c|c|c|c|c|c|c|c|c|c|c|c|c|c|c|c|c|}
\hline & PrecSaz & PrecWeQ & PrecDQ & PrecWaQ & PrecCQ & MAH & MIH & MH & $\mathrm{H} 95$ & LH & MAD & MD & D95 & MAA & MIA & MA & A95 & MB & MEB & TB \\
\hline FA & -0.32 & 0.36 & 0.16 & -0.07 & 0.31 & 0.35 & 0.23 & 0.55 & 0.51 & 0.44 & 0.30 & 0.20 & 0.05 & 0.32 & 0.42 & 0.47 & 0.51 & 0.31 & 0.43 & 0.20 \\
\hline $\mathrm{DE}$ & -0.30 & 0.29 & 0.23 & -0.29 & 0.33 & 0.49 & 0.34 & 0.50 & 0.49 & 0.38 & 0.38 & 0.18 & 0.14 & 0.30 & 0.33 & 0.49 & 0.50 & 0.31 & 0.35 & 0.29 \\
\hline MCWD & -0.64 & 0.50 & 0.38 & -0.04 & 0.48 & 0.39 & 0.42 & 0.57 & 0.46 & 0.51 & 0.46 & 0.18 & 0.12 & 0.33 & 0.23 & 0.56 & 0.56 & 0.32 & 0.44 & 0.28 \\
\hline Temp & 0.19 & -0.49 & -0.05 & 0.15 & -0.19 & -0.35 & -0.21 & -0.31 & -0.36 & -0.35 & -0.23 & 0.04 & -0.33 & -0.11 & -0.46 & -0.27 & -0.29 & -0.45 & -0.10 & -0.22 \\
\hline TempMDR & -0.36 & 0.60 & 0.16 & -0.17 & 0.30 & 0.48 & 0.22 & 0.43 & 0.49 & 0.46 & 0.29 & -0.04 & 0.42 & 0.17 & 0.54 & 0.42 & 0.42 & 0.55 & 0.19 & 0.37 \\
\hline Isoter & 0.23 & -0.56 & -0.07 & 0.37 & -0.27 & -0.43 & -0.08 & -0.34 & -0.46 & -0.36 & -0.16 & 0.03 & -0.39 & -0.21 & -0.46 & -0.30 & -0.33 & -0.45 & -0.12 & -0.33 \\
\hline TempSaz & 0.28 & 0.03 & -0.16 & -0.02 & -0.18 & -0.02 & -0.25 & -0.19 & -0.04 & -0.11 & -0.17 & -0.08 & 0.16 & -0.19 & 0.14 & -0.25 & -0.20 & 0.13 & -0.20 & -0.13 \\
\hline TempWM & -0.33 & 0.10 & 0.28 & 0.03 & 0.27 & 0.06 & 0.18 & 0.17 & 0.14 & 0.14 & 0.11 & 0.05 & -0.05 & 0.19 & -0.06 & 0.20 & 0.16 & 0.00 & 0.25 & 0.22 \\
\hline TempCM & 0.15 & -0.43 & 0.00 & 0.11 & -0.13 & -0.34 & -0.14 & -0.27 & -0.34 & -0.32 & -0.19 & 0.04 & -0.36 & -0.06 & -0.43 & -0.23 & -0.26 & -0.44 & -0.07 & -0.21 \\
\hline TempAR & -0.35 & 0.63 & 0.13 & -0.19 & 0.31 & 0.50 & 0.24 & 0.42 & 0.53 & 0.48 & 0.31 & -0.03 & 0.45 & 0.18 & 0.53 & 0.41 & 0.43 & 0.59 & 0.22 & 0.39 \\
\hline TempWeQ & 0.36 & -0.62 & -0.16 & 0.29 & -0.34 & -0.49 & -0.29 & -0.46 & -0.48 & -0.47 & -0.34 & -0.04 & -0.40 & -0.23 & -0.49 & -0.42 & -0.43 & -0.53 & -0.23 & -0.36 \\
\hline TempDQ & -0.05 & -0.30 & 0.10 & 0.12 & 0.00 & -0.22 & -0.01 & -0.08 & -0.19 & -0.14 & -0.04 & 0.09 & -0.29 & 0.01 & -0.35 & -0.04 & -0.08 & -0.34 & 0.06 & -0.12 \\
\hline TempWaQ & 0.25 & -0.51 & -0.08 & 0.19 & -0.22 & -0.40 & -0.21 & -0.36 & -0.38 & -0.38 & -0.25 & 0.04 & -0.35 & -0.13 & -0.49 & -0.31 & -0.33 & -0.46 & -0.11 & -0.26 \\
\hline TempCQ & -0.02 & -0.34 & 0.07 & 0.15 & -0.05 & -0.25 & -0.02 & -0.10 & -0.23 & -0.18 & -0.07 & 0.06 & -0.33 & -0.01 & -0.37 & -0.05 & -0.09 & -0.39 & 0.01 & -0.13 \\
\hline Prec & -0.63 & 0.59 & 0.44 & 0.11 & 0.55 & 0.36 & 0.24 & 0.44 & 0.50 & 0.50 & 0.26 & 0.11 & 0.19 & 0.30 & 0.31 & 0.39 & 0.40 & 0.39 & 0.36 & 0.39 \\
\hline PrecWM & -0.45 & 0.81 & 0.20 & -0.06 & 0.40 & 0.52 & 0.36 & 0.51 & 0.78 & 0.75 & 0.35 & 0.03 & 0.29 & 0.44 & 0.34 & 0.52 & 0.55 & 0.53 & 0.35 & 0.57 \\
\hline PrecDM & -0.29 & -0.12 & 0.64 & 0.07 & 0.44 & 0.06 & -0.06 & -0.03 & 0.06 & -0.01 & 0.02 & 0.18 & 0.05 & -0.08 & 0.02 & -0.15 & -0.12 & 0.09 & 0.08 & 0.02 \\
\hline PrecSaz & & -0.50 & -0.62 & 0.12 & -0.78 & -0.38 & -0.36 & -0.52 & -0.43 & -0.46 & -0.37 & -0.11 & -0.12 & -0.26 & -0.19 & -0.51 & -0.47 & -0.27 & -0.28 & -0.38 \\
\hline PrecWeQ & & & 0.22 & -0.09 & 0.41 & 0.42 & 0.28 & 0.54 & 0.65 & 0.61 & 0.26 & 0.04 & 0.29 & 0.37 & 0.42 & 0.52 & 0.52 & 0.50 & 0.29 & 0.51 \\
\hline PrecDQ & & & & 0.11 & 0.75 & 0.25 & 0.11 & 0.27 & 0.32 & 0.28 & 0.16 & 0.15 & 0.05 & 0.13 & 0.12 & 0.20 & 0.20 & 0.21 & 0.21 & 0.21 \\
\hline PrecWaQ & & & & & -0.13 & -0.20 & -0.32 & -0.23 & -0.06 & -0.07 & -0.30 & -0.09 & -0.08 & -0.16 & -0.06 & -0.25 & -0.20 & -0.02 & -0.12 & -0.04 \\
\hline PrecCQ & & & & & & 0.40 & 0.33 & 0.42 & 0.49 & 0.41 & 0.30 & 0.22 & 0.15 & 0.25 & 0.18 & 0.35 & 0.35 & 0.34 & 0.34 & 0.29 \\
\hline MAH & & & & & & & 0.25 & 0.42 & 0.68 & 0.68 & 0.55 & -0.03 & 0.44 & 0.24 & 0.33 & 0.38 & 0.40 & 0.54 & 0.14 & 0.48 \\
\hline MIH & & & & & & & & 0.44 & 0.32 & 0.42 & 0.52 & 0.08 & 0.18 & 0.34 & -0.06 & 0.47 & 0.51 & 0.26 & 0.29 & 0.18 \\
\hline $\mathrm{MH}$ & & & & & & & & & 0.46 & 0.56 & 0.31 & 0.16 & 0.15 & 0.56 & 0.38 & 0.80 & 0.89 & 0.27 & 0.47 & 0.38 \\
\hline H95 & & & & & & & & & & 0.78 & 0.42 & 0.07 & 0.39 & 0.29 & 0.35 & 0.40 & 0.45 & 0.66 & 0.31 & 0.55 \\
\hline LH & & & & & & & & & & & 0.52 & -0.01 & 0.41 & 0.45 & 0.28 & 0.51 & 0.58 & 0.57 & 0.27 & 0.60 \\
\hline MAD & & & & & & & & & & & & 0.01 & 0.31 & 0.19 & 0.00 & 0.35 & 0.35 & 0.39 & 0.16 & 0.25 \\
\hline MD & & & & & & & & & & & & & 0.27 & 0.06 & 0.09 & -0.04 & 0.06 & 0.19 & 0.58 & -0.22 \\
\hline D95 & & & & & & & & & & & & & & -0.01 & 0.15 & 0.03 & 0.14 & 0.70 & 0.28 & 0.16 \\
\hline MAA & & & & & & & & & & & & & & & 0.18 & 0.55 & 0.61 & 0.06 & 0.28 & 0.28 \\
\hline MIA & & & & & & & & & & & & & & & & 0.30 & 0.31 & 0.32 & 0.24 & 0.31 \\
\hline MA & & & & & & & & & & & & & & & & & 0.87 & 0.12 & 0.30 & 0.32 \\
\hline A95 & & & & & & & & & & & & & & & & & & 0.24 & 0.39 & 0.37 \\
\hline MB & & & & & & & & & & & & & & & & & & & 0.35 & 0.39 \\
\hline MEB & & & & & & & & & & & & & & & & & & & & 0.07 \\
\hline TB & & & & & & & & & & & & & & & & & & & & \\
\hline
\end{tabular}


Table S4. Pre-selected environmental and forest structure variables used in the analyses of the forest-plots of the southern Amazon border. $\mathrm{FA}=$ fragment area (ha), $\mathrm{DE}=$ distance to the edge $(\mathrm{m}), \mathrm{FC}=$ forest cover $(\%)$, Temp $=$ mean annual temperature $\left({ }^{\circ} \mathrm{C}\right)$, PrecWM $=$ precipitation of wettest month $(\mathrm{mm}), \mathrm{MCWD}=$ maximum climatological water deficit $(\mathrm{mm}), \mathrm{MH}=$ median height and $\mathrm{H} 95=95$ percentile, $\mathrm{MD}=$ median diameter and $\mathrm{D} 95=95$ percentile, $\mathrm{MA}=$ median allometric ratio $(H: D)$ and $\mathrm{A} 95=95$ percentile, $\mathrm{MB}=\mathrm{mean}$ biomass $(\mathrm{Mg})$, and $\mathrm{TB}=$ total biomass .

\begin{tabular}{lrrrrrrrrrr}
\hline \multirow{2}{*}{ Forest plots } & \multicolumn{9}{c}{ Environmental predictors } & \multicolumn{4}{c}{ Vegetation descriptors } \\
\cline { 2 - 12 } & FA & \multicolumn{1}{c}{ DE } & FC & Temp & PrecWM & MCWD & H95 & D95 & A95 & MB \\
\hline FEP-01 & 870 & 1,030 & 99 & 25.5 & 291 & -435.02 & 20.0 & 33.6 & 1.19 & 0.24 \\
FEP-02 & 2,035 & 1,000 & 100 & 25.6 & 289 & -435.02 & 20.1 & 36.6 & 1.34 & 0.25 \\
FEP-03 & 8,432 & 990 & 98 & 24.9 & 285 & -434.01 & 19.8 & 40 & 1.18 & 0.27 \\
FEP-04 & 16,901 & 520 & 74 & 25.1 & 292 & -428.93 & 20.0 & 37.8 & 1.26 & 0.25 \\
FEP-05 & 16,901 & 329 & 100 & 25.0 & 291 & -428.93 & 20.0 & 37.8 & 1.29 & 0.25 \\
FEP-06 & 45,459 & 3,600 & 100 & 26.9 & 298 & -411.82 & 22.0 & 41.4 & 1.19 & 0.32 \\
FEP-07 & 9,789 & 1,180 & 100 & 26.1 & 309 & -397.35 & 20.5 & 35.4 & 1.40 & 0.25 \\
FES-01 & 4,968 & 1,350 & 78 & 25.2 & 274 & -468.04 & 20.4 & 40.4 & 1.00 & 0.31 \\
FES-02 & 3,499 & 160 & 69 & 24.1 & 283 & -433.5 & 18.3 & 39.4 & 1.32 & 0.27 \\
FES-03 & 17,624 & 90 & 58 & 26.7 & 293 & -388.22 & 21.0 & 35.4 & 1.27 & 0.25 \\
FES-04 & 13,039 & 860 & 88 & 26.8 & 289 & -388.22 & 20.8 & 39.3 & 1.17 & 0.31 \\
FES-05 & 15,680 & 2,980 & 100 & 26.6 & 278 & -387.33 & 19.3 & 33.8 & 1.16 & 0.24 \\
FOA-01 & 12,066 & 900 & 98 & 25.1 & 311 & -420.38 & 25.3 & 44.8 & 1.37 & 0.39 \\
FOA-02 & 17,628 & 5,440 & 100 & 25.5 & 390 & -342.12 & 27.8 & 42.6 & 1.42 & 0.43 \\
FOA-03 & 17,628 & 5,410 & 50 & 25.6 & 390 & -342.12 & 28.1 & 42.3 & 1.37 & 0.41 \\
FSI -01 & 21 & 1 & - & 27.3 & 273 & -440.57 & 13.6 & 32.3 & 0.93 & 0.14 \\
FSI -02 & 378 & 1 & - & 27.2 & 277 & -454.52 & 15.0 & 35.2 & 0.92 & 0.19 \\
FSI -03 & 164 & 1 & - & 27.1 & 273 & -457.47 & 14.0 & 24.4 & 0.99 & 0.12 \\
FSI -04 & 605 & 1 & - & 27.1 & 278 & -454.52 & 15.7 & 28.1 & 1.02 & 0.15 \\
FSI -06 & 5 & 1 & - & 27.1 & 274 & -457.47 & 13.9 & 40.3 & 0.75 & 0.19 \\
FSI -07 & 8 & 1 & - & 27.0 & 278 & -444.82 & 15.6 & 45.0 & 0.77 & 0.3 \\
FTP-01 & 234 & 150 & 38 & 24.7 & 308 & -436.02 & 26.8 & 51.9 & 1.14 & 0.48 \\
FTP-02 & 29,560 & 2,720 & 71 & 24.9 & 302 & -429.99 & 22.0 & 34.7 & 1.16 & 0.29 \\
FTP-03 & 85 & 80 & 30 & 24.7 & 294 & -433.5 & 24.0 & 45.3 & 1.09 & 0.52 \\
\hline & & & & & & & & & &
\end{tabular}


A

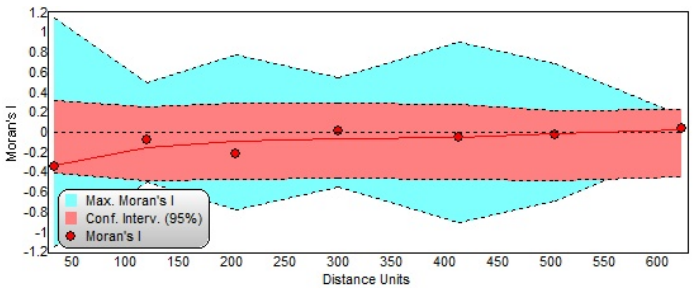

C

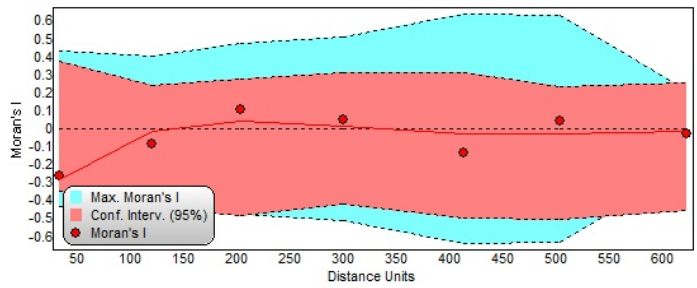

B

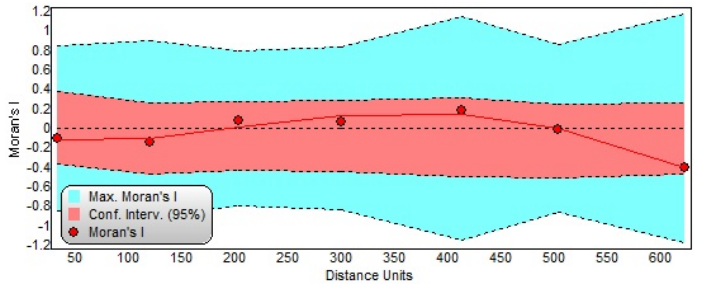

D

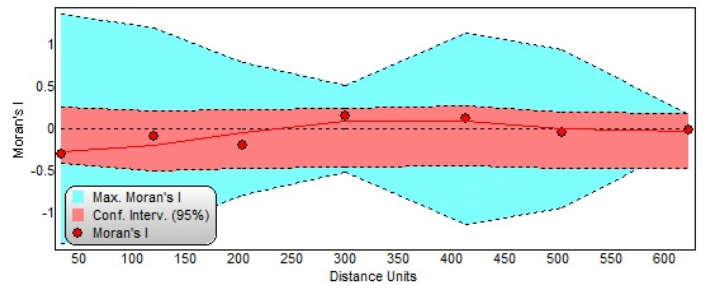

Figure S5. Spatial autocorrelation of the residuals of each model, based in Moran's I index for: $\mathrm{A}=$ height, $\mathrm{B}=$ diameter, $\mathrm{C}=$ allometric ratio $(H: D)$, and $\mathrm{D}=$ biomass of the forests plots in the southern Amazon border. 
Table S6. Comparison of the forest structure variables of the forests in the southern Amazon border, based on the Kruskal-Wallis nonparametric analysis of variance $(\mathrm{H})$. $\mathrm{MH}=$ median height and $\mathrm{H} 95=95$ percentile, $\mathrm{MD}=$ median diameter and $\mathrm{D} 95=95$ percentile, $\mathrm{MA}=$ median allometric ratio $(H: D)$ and $\mathrm{A} 95=95$ percentile, $\mathrm{MB}=$ mean biomass $(\mathrm{Mg})$, and $\mathrm{TB}=$ total biomass. Values on different lines within the same column followed by different letters are significantly different based on Dunnett's post hoc test with the Bonferroni correction.

\begin{tabular}{|c|c|c|c|c|c|c|c|c|}
\hline Forests & \multicolumn{2}{|c|}{ H95 } & \multicolumn{2}{|c|}{ D95 } & \multicolumn{2}{|c|}{ A95 } & \multicolumn{2}{|c|}{ MB } \\
\hline FEP-01 & 19.3 & afg & 31.5 & acd & 1.17 & aefghi & 0.25 & adef \\
\hline FEP-02 & 19.3 & afg & 33.1 & abcd & 1.27 & afg & 0.25 & abdef \\
\hline FEP-03 & 19.0 & $\mathrm{fg}$ & 37.5 & $\mathrm{ab}$ & 1.10 & deghi & 0.27 & abdef \\
\hline FEP-04 & 19.0 & $\mathrm{fg}$ & 33.9 & abcd & 1.20 & afghi & 0.25 & abdef \\
\hline FEP-05 & 19.7 & afg & 35.1 & abd & 1.21 & afgh & 0.26 & abdef \\
\hline FEP-06 & 20.4 & afg & 38.1 & $\mathrm{ab}$ & 1.12 & defghi & 0.33 & $\mathrm{abf}$ \\
\hline FEP-07 & 19.9 & afg & 32.8 & abcd & 1.36 & $\mathrm{a}$ & 0.25 & abdef \\
\hline FES-01 & 17.6 & def & 33.8 & abcd & 0.94 & bcd & 0.30 & abdef \\
\hline FES-02 & 18.0 & cdef & 35.9 & $\mathrm{ab}$ & 1.26 & afg & 0.28 & abef \\
\hline FES-03 & 20.1 & afg & 34.4 & abcd & 1.19 & afghi & 0.26 & abdef \\
\hline FES-04 & 19.6 & afg & 38.2 & $\mathrm{ab}$ & 1.13 & defghi & 0.32 & $\mathrm{abf}$ \\
\hline FES-05 & 18.2 & ef & 31.9 & acd & 1.12 & defghi & 0.25 & adef \\
\hline FOA-01 & 24.0 & a & 38.8 & $\mathrm{ab}$ & 1.29 & afg & 0.39 & $\mathrm{ab}$ \\
\hline FOA-02 & 25.7 & a & 39.4 & $\mathrm{ab}$ & 1.39 & $\mathrm{a}$ & 0.44 & $a b$ \\
\hline FOA-03 & 24.8 & ag & 38.3 & $\mathrm{ab}$ & 1.31 & af & 0.41 & $\mathrm{ab}$ \\
\hline FSI-01 & 13.1 & bc & 30.5 & acd & 0.84 & $\mathrm{bc}$ & 0.18 & cde \\
\hline FSI-02 & 14.2 & bcde & 31.6 & acd & 0.85 & $\mathrm{bc}$ & 0.20 & cdef \\
\hline FSI-03 & 13.1 & bcd & 24.5 & c & 0.97 & bcd & 0.12 & c \\
\hline FSI-04 & 14.3 & bcde & 27.0 & $\mathrm{~cd}$ & 0.98 & bcde & 0.16 & $\mathrm{~cd}$ \\
\hline FSI-05 & 11.9 & $\mathrm{~b}$ & 35.2 & $\mathrm{ab}$ & 0.66 & $\mathrm{~b}$ & 0.23 & acdef \\
\hline FSI-06 & 13.4 & bcd & 40.5 & $\mathrm{ab}$ & 0.61 & b & 0.32 & $\mathrm{abf}$ \\
\hline FTP-01 & 23.5 & ag & 43.2 & b & 1.06 & cdehi & 0.47 & b \\
\hline FTP-02 & 19.7 & afg & 33.1 & abd & 1.11 & deghi & 0.29 & abef \\
\hline FTP-03 & 21.1 & afg & 42.8 & $\mathrm{ab}$ & 1.02 & bcdei & 0.52 & abdef \\
\hline
\end{tabular}


Table S7. Generalized linear models of the factors that influence forest structure of the vegetation in forest plots of the southern Amazon border. Temp = mean annual temperature, $\mathrm{MCWD}=$ maximum climatological water deficit, $H: D=$ allometric $H: D$ ratio, $\mathrm{FES}=$ seasonal semi-deciduous forest-plots, FOA $=$ open rainforest-plots. Significant effects $(p \leq 0.05)$ are shown in bold type.

\begin{tabular}{ccccc}
\hline Factors & Estimate & Standard & $t$ & $P$ \\
\hline Height 95 percentile & & & & \\
Intercept & 2.462 & 1.229 & 2.003 & 0.070 \\
FES & -0.206 & 0.177 & -1.161 & 0.270 \\
FOA & 1.848 & 0.262 & 7.060 & $\mathbf{0 . 0 0 0}$ \\
MCWD & 0.007 & 0.003 & 2.340 & $\mathbf{0 . 0 3 9}$ \\
\hline H:D 95 percentile & & & & \\
Intercept & 8.630 & 2.679 & 3.221 & $\mathbf{0 . 0 0 7}$ \\
MCWD & 0.021 & 0.007 & 3.230 & $\mathbf{0 . 0 0 7}$ \\
Temp & -0.497 & 0.230 & -2.159 & 0.052 \\
\hline
\end{tabular}

